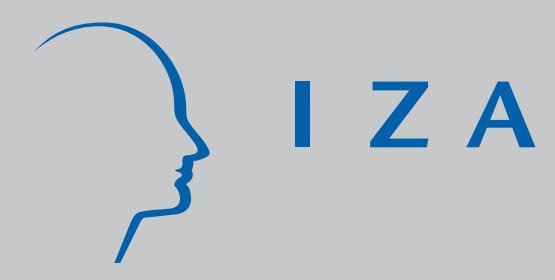

IZA DP No. 1688

How Do Marital Status, Wage Rates, and Work Commitment Interact?

Avner Ahituv

Robert I. Lerman

J uly 2005 


\title{
How Do Marital Status, Wage Rates, and Work Commitment Interact?
}

\author{
Avner Ahituv \\ University of Haifa \\ Robert I. Lerman \\ American University, \\ Urban Institute and IZA Bonn
}

Discussion Paper No. 1688

July 2005

IZA

P.O. Box 7240

53072 Bonn

Germany

Phone: +49-228-3894-0

Fax: +49-228-3894-180

Email: iza@iza.org

\begin{abstract}
Any opinions expressed here are those of the author(s) and not those of the institute. Research disseminated by IZA may include views on policy, but the institute itself takes no institutional policy positions.

The Institute for the Study of Labor (IZA) in Bonn is a local and virtual international research center and a place of communication between science, politics and business. IZA is an independent nonprofit company supported by Deutsche Post World Net. The center is associated with the University of Bonn and offers a stimulating research environment through its research networks, research support, and visitors and doctoral programs. IZA engages in (i) original and internationally competitive research in all fields of labor economics, (ii) development of policy concepts, and (iii) dissemination of research results and concepts to the interested public.
\end{abstract}

IZA Discussion Papers often represent preliminary work and are circulated to encourage discussion. Citation of such a paper should account for its provisional character. A revised version may be available directly from the author. 


\title{
ABSTRACT \\ How Do Marital Status, Wage Rates, and Work Commitment Interact?*
}

\begin{abstract}
How marriage interacts with men's earnings is an important public policy issue, given debates over programs to directly encourage healthy marriages. This paper generates new findings about the earnings-marriage relationship by estimating the linkages between marriage, work commitment, and wage rates. Unlike other studies of the marital wage premium for men, we examine how marital status and marital transitions affect hours worked as well as wage rates, take account of the feedback effect on wage rates and earnings associated with marriage effects on hours worked, estimate marriage effects on black and low skill men, control for several dimensions of selection, and follow men from age 17-40. We find that marriage increases men's earnings by about 20 percent and also find a rise in wage rates and hours worked increases marriage. These findings suggest that both marriageenhancing and earnings-enhancing policies can set off a virtuous circle, in which marriage and earnings reinforce each other over time. Unmarried men who appear unable to support a family because of low current earnings are likely to become more adequate breadwinners once they marry. Thus, if proposed programs are able to increase the utility from and appreciation of marriage, they are likely to generate earnings gains for men as an important side effect.
\end{abstract}

JEL Classification: $\quad \mathrm{C} 23, \mathrm{~J} 12, \mathrm{~J} 15, \mathrm{~J} 22, \mathrm{~J} 31, \mathrm{~J} 88$

Keywords: labor supply, wage determinants, marriage, marital dissolution

Corresponding author:

Robert I. Lerman

Urban Institute

2100 M Street, NW

Washington, DC 20037

USA

Email: blerman@ui.urban.org

\footnotetext{
* The authors are grateful for financial support from the National Institute for Child Health and Human Development, for research assistance by Henry Chen, and for suggestions from David Ribar. The authors also thank the Institute for the Study of Labor (IZA) in Bonn, Germany for hosting them during the preparation of part of this paper.
} 


\subsection{Introduction}

The decline in marriage and associated two-parent families in the United States continues to complicate efforts to reduce child poverty. ${ }^{1}$ Recognizing the apparent link between family structures and poverty, policymakers have consistently built family-related provisions into welfare legislation. For example, the 1996 reforms funded teen pregnancy prevention initiatives, strengthened paternity establishment procedures, bolstered child-support enforcement, expanded welfare benefits for twoparent families, and provided single parents with child care. The Bush Administration has proposed a direct intervention to promote healthy marriages. ${ }^{2}$

Although a primary rationale for the initiative is to improve the life chances of children, a variety of studies suggest increases in healthy marriages may yield other benefits, including better health, lower crime, and reduced domestic violence (Waite and Gallagher 2000; Lerman 2002; and Ribar 2003). This paper concentrates on another potential benefit from marriage- the higher earnings of men. This interaction between marriage and earnings is particularly controversial. Some opposing the marriage initiative argue that low-income women do not marry largely because of the dearth of men with jobs and adequate earnings. ${ }^{3}$ From this perspective, the employment and earnings of men are the key determinant of marriage. An alternative view is that marriage increases employment and earnings partly by stabilizing men's lives, increasing their motivation, and signaling their reliability to employers.

\footnotetext{
${ }^{1}$ The negative association with poverty and inequality is well documented. Single-parent families housed 60 percent of poor persons in families with children, but only 25 percent of all persons in families with children. Families headed by unmarried women accounted for over 70 percent of chronically poor individuals living in families with children. Recent estimates suggest that were marriage rates at levels of the early 1970s, the 1998 US child poverty rate would have been 3.5 percentage points lower (Thomas and Sawhill 2002), as would income inequality among children (Lerman 1996).

${ }^{2}$ For a review of the history leading to this proposal, see Nock (2005).

${ }^{3}$ See, for example, the editorial "Heartless Marriage Plans" from the New York Times, January 17, A14.
} 
Determining whether and to what extent marriage is a cause or simply an effect of higher men's earnings is a complex problem. Marriage might alter how much men and women work. Changes in work effort, in turn, influence each partner's accumulation of human capital and wage rates. For those who increase their human capital, higher wages over time makes work more attractive, though the income effect lessens the urgency of long hours. Added work experience and higher wages can increase the likelihood of entering marriage or remarriage and reduce the likelihood of divorce. Marriage may also raise or lower wage rates, by influencing a worker's time horizon, investment, motivation, and acceptance of unpleasant but well-paying jobs. These marriage-induced effects on wages may indirectly lead to an increased work commitment by men.

The literature on these key relationships is extensive and goes back many years. Research confirms an earnings advantage for married men dating back at least to the $19^{\text {th }}$ century (Goldin 1990). Using cross country data from the 1980s, Schoeni (1995) finds a wage advantage of married over single men in all 14 countries studied. The marriage earnings premium estimated from 19401980 decennial Census data has been consistently significant at percentages ranging from +11 percent in 1959 to +23 percent in 1969 (Loh 1996). ${ }^{4}$ Even among men with poor health, marriage appears to increase hours worked (Parsons 1977).

The close associations between marital status and male earnings have continued through the latest data. Using the March 2004 Current Population Survey (CPS), we estimated standard human capital regressions, expanded to include race, Hispanic origin, and presence of children. Among men, ages 25-49, the coefficient on being married implied a 34 percent earnings advantage over the never-married, a 25 percent advantage over separated men, and a 21 percent advantage over divorced men. These marriage-related differentials are extremely high, about two to three times the

\footnotetext{
${ }^{4}$ These marriage impacts on earnings control for education, years of potential experience, potential experience squared, race, immigrant status, veteran status, region, occupation, and industry.
} 
differentials associated with a year of schooling. While these cross-sectional estimates likely overstate marriage effects on earnings because they fail to account for unobserved heterogeneity, they offer a strong motivation for the research trying to isolate the factors underlying marriage-earnings relationship.

Several studies have examined the positive association between marriage and earnings, especially the marriage wage premium. ${ }^{5}$ Some have looked at the possibility that married men are a select group that would earn high wage rates whether or not they married and avoided divorce. Other studies have analyzed the impact of men's wage rates and earnings on marital status. But, very few have estimated the effects of marital status on the commitment to work or distinguished the marriage-induced gains in hours worked from the induced gains in wage rates.

In a companion paper (Ahituv and Lerman 2004), we modeled and estimated the relationships between job stability, marital stability and wage rates among men. The focus was on young men moving through their 20s and early 30 s and how multiple job changes affected wage growth and the transitions to marriage, divorce, and remarriage. Among the key findings were robust negative impacts of job changing on wage rates and on flows into marriage.

This paper moves beyond earlier studies in order to estimate the links between marriage, work commitment, and wage rates. We follow young men from age 17 through their late 30 s. We incorporate marital status effects on hours worked as well as wage rates. We take account of the feedback effect in which marriage affects hours worked, which affect work experience, and ultimately wage rates. We control for various types of selection that might bias the findings and we present estimates based on a variety of specifications. We incorporate linkages between the

\footnotetext{
${ }^{5}$ Though in principle the earnings gains from marriage could come from added hours or higher wages, most of the literature examines how marriage affects the wage rates of men (Korenman and Newmark 1991; Daniel 1995; Cornwell and Rupert 1997; Gray 1996; Loh 1996; Chun and Lee 2001; Ginther and Zavodny 2001; and Stratton 2002) and not their labor supply.
} 
unobserved individual characteristics affecting hours worked and wage rates into the estimates of the determinants of marital flows.

The findings reveal substantial and statistically significant effects of marital status on work commitment and wage rates, even after taking account of unobserved heterogeneity or selection effects. The impact of being in a continuing marriage involves a 21 percent gain in earnings relative to remaining single and a 19 percent gain relative to remaining divorced. At the same time, higher wages and working hours increase the odds of entering marriage and remarriage and reduce the odds of divorce.

The paper continues as follows. The next section examines selected studies of marriage and men's wages that incorporate controls for selection. Section 3 describes the data and presenta our methodology and estimation strategy. In section 4, we examine basic statistics on men's marital flows, wages, and hours worked. Section 5 analyzes the multivariate results on wage rates, hours worked, and the dynamics of marital status. In section 6, we highlight the key findings and their implications.

\subsection{Selected Studies of Marriage and Labor Market Outcomes of Men}

Of the large body of research studies on the relationship between marriage and men's earnings, this section reviews only selected studies, nearly all of which use controls for the selection

problem. All focus on causal impacts in one direction, either from marital status to wages or from labor market outcomes to marital status.

Authors estimating the effect of marriage on wages have tried to capture unobserved heterogeneity with panel data and specifications involving individual-specific fixed effects and/or random effects. In one application examining the log of wage rates of young white men from 1976 to 1980, Korenman and Newmark (1991) estimate an 11 percent marriage premium among white 
men without random effects and about 6 percent with random effects. Divorce reduced wage rates relative to marriage, but only by about 2 percent. The authors note that these are average effects of men who are young and thus in relatively short marriages (or short divorces). Allowing the marriage premiums to rise with the duration of marriage, Korenman and Newmark find wages rise with marital tenure at about 2 percent per year in the first two years and 1 percent thereafter. Their results yield a marriage premium reaching about 15 percent for those with the average years of marriage; this selection-adjusted premium is about 90 percent of the unadjusted premium. ${ }^{6}$

Expanding the data for one additional year, to follow a cohort of 19-29 year-old white men in 1970 to 29 to 39 in 1980, Cornwell and Rupert (1997) find marriage premiums of 8.3 percent when estimated from random effects and 5.6 percent, when estimated from fixed effects. Using the same models as Korenman and Neumark, Gray (1997) compares the NLS cohort of 24-31 year-olds in 1976 with the NLSY79 cohort of 24-31 year-olds in 1989. He follows white males over three specific years in each cohort. Gray's results suggest that marriage gains fell sharply over time. In the NLSY79 cohort, the coefficient on the marriage dummy is only 1.4 percent and is not statistically significant.

A recent study (Antonovics and Town 2004) sought to estimate a causal effect of marriage on wage rates by using data on a 136 pairs of monozygotic twins from Minnesota to deal with the problem of unobserved heterogeneity. Assuming that both members of a twin pair have the same unobserved individual specific earnings endowment and family-specific earnings endowment, the authors find a 26 percent marriage wage premium within twin pairs, a level somewhat higher than the estimate derived from cross section regressions that take no account of the men's status as twins. This evidence persuasively shows the absence of a selection effect, but the results may not generalize to a broader population.

\footnotetext{
${ }^{6}$ Daniel's 1995 analysis of a more recent cohort of young men found similar overall effects, with slightly higher shares
} 
Some studies have focused on the reasons for a marital wage premium. Reed and Harford (1989) find evidence that some of the marriage wage premium is the result of compensating differentials - the fact that married men are more willing than unmarried men to take jobs that are more difficult, dangerous or unpleasant in return for a higher wage. Kenny (1983) argues that the marriage premium is partly a return on the higher human capital investment that married men make by working longer hours and gaining more work experience. Hersch and Stratton (2000) examine and reject the hypothesis that household specialization accounts for a good deal of the male wage premium. Using a fixed effect estimation approach with data from the National Survey of Families and Households, they find that including a measure of the hours of housework undertaken by men does nothing to reduce the marital wage premium.

Chun and Lee (2001) account for selection by applying a switching model to cross-sectional data. The marriage equation is identified based on an index of the marriage market, predicted hours of a wife's work, and the mother's country of birth-factors that should influence marriage but not directly affect wages. The authors use a sample of all 18-40 year-old working males drawn from the March 1999 CPS. The estimated marriage premiums are about 12 percent, both from an OLS equation on log wage rates and from the switching equation. These results cast doubt on the importance of the selection effect on the marriage premium. Chun and Lee find that the effects on wage rates are much higher in marriages in which wives did not work (about 27 percent) than in cases in which they did work (a 15 percent effect at 20 hours of work by wives). This result is consistent with the theory that husband-wife specialization is a big reason for the marriage impact on wages. However, such an interpretation may not be valid, given the results from Hersch and Stratton (2000) that men's marriage premium is unaffected by the hours they work at home. The determinants of marriage were expected in some ways but not in others. Tight marriage markets 
reduced marriage probabilities while higher predicted hours of wives raised them. Surprisingly, higher levels of education lowered the likelihood of marriage.

Overall, the estimates of the marriage premium on wage rates for men vary across studies, perhaps because of the differences in samples and specifications. Although the estimates range from a high of 27 percent for $18-40$ year-old men with nonworking wives and 26 percent among twins from Minnesota to a low of 1.4 percent among white men ages $24-31$ in 1989, several are in the range of 6-15 percent. None of the studies take account of the direct and indirect effects on hours worked and thus they are likely to understate the full impact of marital status on earnings (and thus the capacity to support a family). The three studies based on panel data use only a few years of information. All but one study includes only white young men.

Turning to the impacts of male earnings on marital status, we see a variety of studies. Some create empirical tests of the Wilson hypothesis (Wilson 1987), which explains the decline in marriage rates among black men as largely the result of their ability to obtain good, steady jobs. While researchers show evidence that better job options for men lead to higher marriage rates ${ }^{7}$, worsening job opportunities over the 1970s and 1980s accounted for only a modest reduction in the decline in marriage (Wood 1995).

Studies often use duration analysis to determine how employment, unemployment, wage rates, or earnings affect flows into a marital or cohabitation status. For example, Oppenheimer (2003) uses event-history, multinomial logit equations to determine how time since leaving school, current earnings, and recent work experience influenced the risk of entering cohabitation or marriage (if single) and the risk of entering marriage or separating (if cohabiting). High earnings increased entry into marriage but not cohabitation, and less than full-time work reduced the

\footnotetext{
7 See, for example, Manning and Smock (1995), Call and Teachman (1996), Presser (2000), Smock and Manning (1997), Teachman, Call, and Carver (1994), Becker, Landes, and Willis (1997), and Weiss and Willis (1997).
} 
likelihood of entering a marriage, but not a cohabiting union. Although the findings are interesting, the study did not control for possible selection bias.

Burgess, Propper and Aassve (2003) examine entry into marriage (among those single) or divorce (among those married) as a function of current and long-term earnings (or wage rates) and other income potentially available in each marital status, including the average earnings of a potential spouse. Using a sample of white men and women in the NLSY79, they take account of selection by substituting each individual's fixed wage rate or earnings effect in the long run, holding constant for work experience, urban location, local unemployment rate and number of children. This technique limits but does not fully avoid the simultaneity problem, since the estimated fixed effects do not control for contemporaneous or long-term marital status. For men, the results show higher earnings (or wage rates) increase entry into marriage and slow or reduce marital dissolutions while the average wage of a potential mate has virtually no effect. Long-run measures of earnings and wage rates exert a higher impact than do current earnings or wage rates.

Charles and Stephens (2004) uncover evidence that a spouse's displacement from a job increases the transition rate into divorce. Other studies have shown a link between high male earnings inequality and low marriage rates (Gould and Passerman 2003; Loughran 2002). The argument they propose for this relationship is that, the higher is male wage dispersion, the greater are the gains from extending search in the marriage market.

This study goes beyond the existing literature in several ways. First, we cover young men over a substantially longer period of time than other studies. Second, we examine the separate impacts of marital flows, including entry into marriage, divorce, and remarriage and remaining in marriage or divorce. Third, we identify and examine the relationship between two dimensions of selectivity, one affecting the estimates of marital effects on wage rates and a second affecting marital effects on hours worked. Fourth, we use these different dimensions of selectivity to predict flows 
into and out of marriage. Fifth, we examine the sensitivity of the results to a range of specifications, including OLS, fixed effects, and random effects. Finally, unlike most other studies, we include nonwhite young men and provide separate estimates for black men and men with low scores on the Armed Forces Qualification Test (AFQT).

\subsection{The Data and Methods}

\subsection{The Data}

The National Longitudinal Survey of Youth (NLSY79) is an attractive data source for this study because it provides detailed information on respondents' family background, schooling and abilities, marital status, parenthood, work histories and the exact timing of marriages and divorces and other changes in household status. The NLSY79 is a national probability sample of 12,686 individuals (6,403 male) ages 14 to 21 as of January 1, 1979 who were re-interviewed annually until 1994 and semi-annually through $2004 .^{8}$

In deriving our primary analysis sample of male respondents, we wanted to include full work and marriage histories. Given evidence of low returns to work-while-in-school (Hotz et al. 2002) and the fact that less than one percent of 17 year-olds are married, we chose to follow job and marital histories from age 17. As a result, youth become part of our sample only after reaching 17 in 1979, 1980, 1981, 1982, or 1983. Because information about jobs held prior to 1978 is not always complete, we restricted the multivariate analyses to individuals who were ages 14-19 in 1979, thereby excluding 1,772 cases. Next, because the NLSY itself dropped some groups from follow-up interviews, we excluded the low-income white oversample (521 cases) and the military oversample (237 cases). The absence of data on wage rates and hours worked during military service forced us

\footnotetext{
${ }^{8}$ The survey consists of a cross section sample of 6,111 youth representing the non-institutionalized population born between January 1, 1957 and December 31, 1964, a supplemental sample of 5,295 non-institutionalized black, Hispanic, and low-income white youth, and an armed forces sample of 1,280 youth. The military sample was discontinued in 1986 and the economically disadvantaged non-black, non-Hispanic supplementary sample was dropped in 1991. Of the
} 
to exclude an additional 509 males who served time in the military. Finally, we chose to include only those completing at least 10 interviews, a decision that reduced the sample by 366 cases. The result is a sample of 2,863 male respondents and 61,234 male person-years. For Table 2, in order to follow the same individuals as they aged to age 40 , we used a subsample made up of those in the primary sample who were ages 17-19 in 1979.

To incorporate the role of neighborhood on life-cycle paths, we added data on county employment growth, income levels, unemployment rates, marriage, and divorce rates. The economic data come from the Bureau of Economic Analysis, Regional Economic Information System. The divorce rates were compiled from the City-County Data book. These variables were merged to the main data, using county codes.

Because our approach emphasizes annual flows, we require annual data on work, wages, and marital status. To obtain these data after 1994, when the NLSY79 began to conduct interviews every two years, we undertook the task of compiling this information from variables capturing dates of various activities. Deriving the estimates of wage rates and annual hours worked involved accessing the NLSY79 work history files. Wage data were available on all jobs between surveys. For those who did not report any work in a particular year, we imputed a wage based on prior year's wage rate. We used information on the dates of marriage and divorce to derive annual marital status flows.'

Our analyses include five dependent variables: wage rates, annual hours of work, and three marital status transitions. Although the data allow us to employ several definitions of family formation, we chose to rely on the formal definition for singles and marriages and a definition of divorce that includes separation. Among the reasons are that most cohabitation leads to separation without children, while most marital separations lead to formal divorces.

remaining sample of 9,964 , nearly 80 percent $(7,724)$ completed interviews in 2002 . At this point, sample members were ages 37-44.

${ }^{9}$ A full description of this procedure appears in Appendix A. 
In examining the dynamics of marital status, we use an exclusive, exhaustive classification system that defines each individual in each year (i.e., each person-year) as:

1) Remaining single, never married,

2) Entering marriage for the first time during this calendar year,

3) Remaining married in the current year after having been married in the prior year (including second marriages),

4) Becoming divorced or separated during this year,

5) Remaining divorced or separated in the current after having been divorced or separated in the prior year, or

6) Remarrying during this calendar year

This classification defines the five dummy variables (with remaining single as the zero category) used as right hand side endogenous explanatory variables in equations predicting labor market outcomes. For marital status transitions as dependent variables, we simplify the categories and focus on the transition rates from being single to first marriage, from marriage to divorce/separation, and from divorce/separation to remarriage.

The definition of the individual's wage rate is the natural log of the hourly rate of pay in the main job during the last annual year. Work effort is defined as hours employed in the prior year. To avoid measurement error, we top-coded the annual hours of work at 3,120 per year (60 hours per week for 52 weeks) or hours above the $93^{\text {rd }}$ percentile.

Descriptive statistics on our sample appear in Appendix Table B-1. Minorities are overrepresented in this sample, with black men contributing about 28 percent of the person-years and Hispanic men contributing another 20 percent. About 7 percent of the person-years involve foreignborn young men. Sample members often came from families with less-educated mothers (the mean education level of mothers is less than 11 years of schooling) and with mothers heading families (18 
percent of person-years). In using this stratified sample, we use weights to make the figures in Tables 1 and 2 nationally representative. For the multivariate analysis, we report estimates based on unweighted data. However, estimates of these relationships with weighted data yielded similar results to those based on unweighted data.

Looking at the means for variables that change over time, we see few person-years of school attendance (17 percent). The mean age of the person-years is about 28 . In the average person-year, sample members had accumulated 3.4 years in marriage, almost 9 years of accumulated work experience, three years of experience on a current job, and 12.5 years of schooling. The average number of hours worked per week is almost 35, or nearly full-time for 50 weeks.

\subsection{Empirical Framework}

This section describes the five sets of equations that estimate the determinants of hours worked, wage rates, and flows into marriage, divorce, and remarriage. We take advantage of the panel data to use two established methods, fixed effects and random effects, to take account of individual-specific unobserved characteristics that may bias estimates of variables of interest.

The equation of hours worked is expressed as,

$$
H_{i t}=X H_{i t} \gamma^{X}+Z H_{i t-1} \gamma^{Z}+M S_{i t} \gamma^{M S}+W_{i t-1} \gamma^{W}+A_{i}^{H}+\varepsilon_{i t} \text {, }
$$

where $i$ represents individual $i$, and $t$ represents year $t$.

In this formulation, annual hours worked, $H_{i t}$ is a linear function of:

(1) Indicators of race and ethnicity, birth cohort, family background variables, AFQT, and local market conditions $(X H)$, where the $H$ part of $X H$ designates those used in the hour's equation.

(2) A vector of variables that measure, at the beginning of each period, the accumulated amounts of schooling, children, and work experience, and tenure in his present job $(\mathrm{ZH})$.

(3) The marital status flows (MS), as specified on page 11.

(4) The natural log of the individual's lagged wage rate $\left(W_{t-1}\right)$. 
(5) A set of unobserved individual characteristics that may affect both hours and marital flows $\left(A^{H}\right)$.

(6) An unobserved time-varying residual, $\varepsilon$.

The unobserved individual characteristics, $A^{H}$, may represent each person's reliability and/or sense of efficacy or other factors which could affect both the probability of marriage, divorce, and remarriage as well as the amount of hours worked. The usual expectation is that ignoring unobserved heterogeneity will lead to an upward bias in estimates of marriage impacts on wages. This is because the unobserved characteristics that increase the likelihood of marriage are likely to have positive effects on hours worked and wage rates. However, a negative selection effect is certainly conceivable as well, since those men who feel less secure about their labor market capabilities may want to share the risks of low earnings with a wife. ${ }^{10}$

Using OLS captures the effects of marital flows on hours worked controlling for an extensive set of observed characteristics in the NLSY as well as matched variables representing local employment conditions. However, since the OLS method combines the unobserved characteristic, $A^{H}$, together with $\varepsilon$ into an overall residual, the results are subject to heterogeneity bias. A fixed effect strategy is one way to deal with this problem; it obtains individual-specific impacts that capture time-invariant unobserved influences on hours worked. With direct estimates of $A^{H}$, the remaining residual $\varepsilon$ will be uncorrelated with the independent variables and thus yield unbiased impacts of marital status.

Fixed effects are of interest, but they prevent us from estimating effects of other timeinvariant characteristics such as race or AFQT scores, and in some cases, they are less efficient than a random effects specification (Hsiao, 1986). Treating $A^{H}$ as a random effect in order to control for unobserved characteristics avoids these problems, but is inappropriate if $A^{H}$ is correlated with other independent variables. We test for this correlation and for the differences in coefficients between 
fixed and random effects (using the Hausman test). Where the correlation is near zero and the coefficients are not significantly different, we focus on results from the random effects specification. However, we present estimates of impacts on wages and hours from both fixed and random effects.

We use a similar approach in estimating how marriage flows affect the natural log of the wage rate $(\mathrm{W})$, as in the following equation:

$$
W_{i t}=X W_{i t} \delta^{X}+Z W_{i t-1} \delta^{Z}+M S_{i t} \delta^{M S}+A H_{i t-1} \delta^{H}+A H_{i t-1}^{2} \delta^{H}+A_{i}^{W}+v_{i t} \text {, }
$$

where $X W$ and $Z W$ are sets of independent variables in the wage equation, $A H$ represents cumulative hours of work experience, $A^{W}$, represents the unobserved characteristics affecting wage rates, and $v$ is a residual uncorrelated with the independent variables.

After estimating (1) and (2), we obtain the unobserved individual effects, $A^{H}$ and $A^{W}$, from both the fixed and random effects specifications. Examining the correlation between $A^{H}$ and $A^{W}$ allows us to determine if a single dimension of unobserved heterogeneity is affecting both hours worked and wage rates. If the correlation is high, it becomes appropriate to estimate the equations jointly, using a procedure that takes account of the cross equation correlations in the error terms.

To analyze the likelihood of never-married men to enter a first marriage, we use a latent variable MS1, that denotes an index of the propensity of individual $i$ at time $t$ to enter into marriage. If the latent variable $M S 1>0$, then the person enters marriage. The latent index is

$$
M S 1_{i t}=X 1 \beta 1^{X}+Z 1_{i t-1} \beta 1^{Z}+W 1_{i t-1} \beta 1^{W}+A H_{i t-1} \beta^{H}+A H_{i t-1}^{2} \beta_{i}^{H}+A 1_{i t}+
$$

where the error term is assumed to be normally distributed with mean zero and variance $\sigma^{2}$. Similarly, we define two other latent variables $M S 2$, and $M S 3$ that denotes entry into divorce, and entry into remarriage.

\footnotetext{
${ }^{10}$ Wilson and Oswald (2005) develop this point theoretically and cite empirical findings of negative marriage selection effects.
} 
We estimate each of the marriage flow equations, such as (3), using a standard probit equation, a probit equation with random effects, and a random effects probit that includes the fixed effects, $A^{H}$ and $A^{W}$, as independent variables. The third equation takes account of the possibility of three dimensions of selectivity. We do not employ fixed effects in the probit context because there is no sufficient statistic allowing conditional fixed effects and unconditional fixed effects are biased.

Before choosing these specifications, we estimated a system of wage rate, hours, and marital flow equations using the Dynamic Selection Control Model (see Ahituv and Lerman 2005) and found that the selectivity terms, $A^{H}$ and $A^{W}$, were uncorrelated. As a result, we employ approaches that can capture the two separate dimensions of selectivity.

\subsection{Age Profiles of Marital Transitions and Labor Market Outcomes}

A useful step in understanding the distinctive marital transition variables used in this study is to look at the evolution by age of the six marital flows described above. Table 1 shows the distribution of all males across marital states (Panel A) and, for selected age groups in Panel B, the rates of entry into first marriage (among men single in the prior year), divorce (among men in a married or remarried state in the prior year), and remarriage (among men in a divorced state in the prior year). Although only about 10 percent or fewer young men in this cohort experienced changes in status within a given year, the cumulative shifts in status are large over men's 20s and early 30s. The share of never-married men dropped from nearly 97 percent at age 18 to 34 percent by age 30 . While the proportion who married peaked at age 23 , entries into marriage continued at a modest pace through the mid-30s and one in five men were still never-married as of age 38.

The proportions subject to various marriage transitions change substantially with age. The share of men in the first two columns is the proportion "at risk" of entering a first marriage and in the entering marriage equation. The proportion "at risk" of divorce is equal to the sum of the third 
and fourth columns, while the proportion "at risk" of remarriage equals the fourth and fifth columns. The share in the entering marriage equation was nearly 100 percent at age 18, but only 27 percent at age 34. Over the same ages, the divorce equation moved from covering virtually no 18 year-olds to over 58 percent of the cohort's 34 year-olds while the remarriage equation gradually raised its coverage from 2-3 percent of 22-23 year-olds to $16-18$ percent of 37-38 year-olds. Within each of the "at risk" groups, the proportions changing status gradually declined with age.

The proportion of men in a first marriage (column 7 ) reached a near peak (49.4 percent) at age 32. After age 32, the number entering a first marriage was offset by the number ending a first marriage. Thus, second marriages become as common as first marriages. Though age-marital status profiles varied widely by race, the proportion in first marriages among Hispanic, black, and white young men was highest at age 32 (not in table). Moving from age 32 through 38, the share in first marriages stayed at about 30 percent of blacks and 54 percent of non-Hispanic whites, but fell slightly from 47 to 45 percent among Hispanic men.

Taken as a whole, the figures in Table 1 reveal the wide variation in age patterns of men's first marriage, divorce, and remarriage, while also showing that the highest rates of transitions take place over the 23 year period covered in this paper.

The tabulations in Table 2 provide age-wage and age-hours worked profiles by marital status for all men in the sample and for black men. The figures show a close connection between marriage and wage rates as well as a highly positive relationship between marriage and annual hours worked. Married men attained higher levels on all the main labor market indicators over divorced/separated and never-married men of the same age. While the literature has largely focused on the marriagewage rate linkage, we also examine the interactions between marriage and hours worked in detail. It is interesting that the wage rate advantage of those in first marriages over never-married widened with age, from 10 percent at age 24, to 20 percent at age 32, to 48 percent at age 40 . This suggests 
the importance of distinguishing between the immediate effects of entering marriage from the longer-term effects. Divorced or separated men had especially low wage rates, even lower than single men at ages 28-40. The married-single wage differential increased faster among black men, rising from 10 to 55 percent as men aged from 24 to 40 .

Married men worked several more weeks per year and hours per week than unmarried men. By age 24, married men were already working 22 percent more hours per year than never-married men. Though the never-married raised their annual hours to almost full-time year-round, the 22 per cent advantage for married men remained through age 36 and reached 34 percent by age 40 . Again, the married-single differential became higher among blacks (reaching 45-65 percent at ages 36-40), mainly because black single men worked a much lower number of hours than did all single men.

These large differentials in hours worked are important not only for their effect on the current earnings of married relative to unmarried men, but also for their long-term impact on wage rates. Work experience is a component of human capital and its impact on wage rates is welldocumented. Thus, to the extent that marriage encourages men to work longer hours, it will also generate wage rate gains in the future. We take this indirect effect of marriage on wages and earnings into account in deriving the marriage earnings premium.

The descriptive results indicate a significant and substantial positive association between men's labor market outcomes and marital status. The question is: to what extent do the associations reflect a causal role for marriage, wages, or work commitment? To answer this question, we turn to the empirical results from models that control for observed and unobserved characteristics. 


\subsection{Estimated Impacts on Hours Worked, Wage Rates, and Marital Flows}

\subsection{How Marital Status Affects Hours Worked}

Table 3 shows estimates from several specifications of the effects of marital status and lagged log wage rates on hours of work. ${ }^{11}$ Separate coefficients represent the impacts of each marital flow dummy variable relative to remaining never-married. The top panel of each table compares OLS, fixed effects, and random effects approaches. The bottom panel covers impacts based on random effects methods for three subgroups: black men, men with lowest 25 percent of test scores on the AFQT, and men under age 30.

The OLS specification in Table 3, which controls for a large number of observable characteristics, yields large and statistically significant coefficients on nearly all the marital flow variables. These estimates are notable since they take account of accumulated weeks of work experience, lagged wage rates, job tenure, age, race, Hispanic origin, being foreign-born, family income, having been charged for an illegal offense by age 17, having 1-2 or 2+ children, years of education, school attendance, residence in an urban area, county unemployment rate, and county employment growth. However, the OLS results are subject to bias because of the presence of unobserved characteristics.

The random and fixed effects estimates in columns 2 and 3 take account of these unobservable, individual-specific characteristics. As expected, unobserved characteristics lower the impacts on marital flows on hours worked, implying a positive selection effect. The fixed effect estimates generate particularly large reductions in marital flow coefficients relative to the OLS estimates. Still, entry into marriage raises work hours by 160 per year over those of otherwise similar never-married men. The gain for those continuing married over the never-married falls to 52 hours per year. This pattern — an immediate jump in hours worked as men enter marriage and a large 
reduction in the marriage effect for those continuing in marriage-is striking. Surprisingly, those in continuing divorces work 51 hours fewer than the never-married. As a result, the hours worked advantage of those in continuing marriages over those in continuing divorces is 103 hours per year (the +52 marriage term minus the -51 divorce term).

The random effects estimates provide other estimates that control for selectivity while at the same time generating impacts of time-invariant variables. In this case, they are no less appropriate than fixed effects estimates, since the selectivity term is uncorrelated with the independent variables. ${ }^{12}$ The marital flow impacts based on random effects fall between the OLS and fixed effects estimates, though somewhat closer to fixed effect than to OLS models. For example, the jump in hours worked that takes place among men in the year they enter marriage is 200 , or between 262 and 160. The differential between those in continuing marriages and continuing divorces, who constitute most of the sample by age 28 , is 110 hours per year (+89.6 minus -20.7$)$, or slightly higher than the 102 hours from fixed effects. Remarriage leads to a slightly lower 99 hour increase in annual time worked over those remaining divorced (+78 minus -21). Thus, whether we use random or fixed effects, marriage significantly increases hours worked.

To see whether men with low marriage rates or low expected wage rates raise their work commitment in response to marriage, we estimate random effects regressions for black men, men with low test scores, and men under 30. The figures in the Panel B of Table 3 generally reveal that the impacts of marriage for these groups are as high as or higher than the impacts for all men in the sample. In all three cases, entering marriage generates an initial work response substantially higher

\footnotetext{
11 The estimates of coefficients and significance levels for all independent variables appear in Appendix Tables B-2 and B-3.

12 We undertake two tests relevant to choosing random versus fixed effects. The first examines the correlation between the error component $\mathrm{A}$, and the other independent variables. Because the correlation was essentially zero, random effects do not yield biased estimates. The second, a Hausman test, indicated that the coefficients from the random effects were significantly different from those in the fixed effect specification. Given these tests and the fact that random effects methods yield estimates of the time-invariant variables, we believe it is appropriate to present both sets of results.
} 
than for the entire sample, with the highest at 265 hours per year among black men. The added hours worked linked to continuing marriage over being never-married varies from 60 per year for blacks, 98 for men with low AFQT, and 119 for those under 30. Relative to a continuing divorce, staying married exerts substantially higher effects, ranging from 128-132 hours per year for low AFQT and black men to 198 hours per year for men under 30. Wage rates significantly affect hours worked but the effects differ by subgroup. As wage rates increase by one percent, black men show no response, young men work 44 hours per year longer and men with low AFQT scores lower work hours by 25 per year. Young men show a higher positive response to higher returns to work than a negative response to higher income; the opposite pattern emerges for men with low AFQT scores.

\subsection{Marital Flow Effects on Wage Rates}

The impacts drawn from OLS, fixed, and random effects equations are presented in Table 4 and reveal the sensitivity of the estimates to alternative specifications. The results provide strong evidence of a substantial and statistically significant marriage wage premium. Controlling for a large number of observable differences between men, the OLS coefficients imply a 12 percent wage gain upon entry into marriage and an 18 percent gain in continuing marriage, relative to remaining nevermarried. Again, given the potential selectivity problem, we turn quickly to the fixed and random effects estimates. They turn out to be quite similar to each other and about one-third lower than OLS effects, indicating a positive selective effect. Since the selectivity effect is again uncorrelated with the independent variables ${ }^{13}$ and a Hausman test shows no significant difference in coefficients between fixed and random effects, our focus is on the random effect estimates, which are more efficient and provide estimates of impacts of time-invariant variables.

Unlike other estimates of marriage wage premiums, our estimates control for accumulated hours worked through the prior year. The highest gains accrue to those in continuing marriage. This

\footnotetext{
13 The actual correlation is 0.046 .
} 
status induces wage rate gains of 12 percent relative to the never-married and 9.4 percent relative to those in continuing divorces. The effect of entry into marriage is smaller, but it is still striking that wage rates rise 8.5 percent within a year in response to entering a first marriage.

The wage impacts of marriage extend to black men and men with low AFQT scores. These subgroup impacts in Table 4, which are derived from random effects regressions, are all statistically significant and broadly similar to those observed for the entire sample. The marriage wage premium for black men is slightly higher relative to the never-married and slightly higher for remarriage, but somewhat lower when comparing those in continuing marriage to those in continuing divorce. Men with low AFQT scores achieve similar gains from marriage compared to the never-married and from remarriage compared to those in continuing divorces. This is striking and important evidence that the marriage premium is not limited to those with the most favorable earnings prospects.

Interestingly, these wage effects of marriage differ in timing from the hours worked effects reported in Table 3. While the wage effects increase in moving from entering a first marriage to continuing in marriage, the effects of marriage on hours worked gradually decline after the initial year of marriage. One possible reason for these differential patterns is that wage gains come as returns on marriage-specific investments, while added hours worked result from motivational factors that peak immediately after a marriage and then settle down to a moderate level.

The human capital derived from accumulated work experience raise wage rates in all specifications. Each additional 1,000 hours of work experience raises wage rates by 2.3 percent. This work experience effect is relevant to the full marriage wage premium through a feedback mechanism. Since marriage raises work hours and work hours raise wages, some of the added wage associated with work experience is indirectly affected by marriage. One added year of continuing marriage (over a continuing divorce) raises hours worked by about 110 hours per year. With each 1,000 hours raising wage rates by 2.3 percent, the added 110 hours would imply a wage gain of 0.21 
percent in each subsequent year. Thus, a single year's marriage-induced gain in hours worked would lead after 10 years to a 2 percent higher wage rates.

Another indication of the full marriage wage rate premium that incorporates marriageinduced increases in hours worked comes from the "No Hours" regression reported in Table 4, panel B. This regression controls for selection with random effects, but excludes the accumulated work experience variables. Note, for example, that the coefficient for continuing marriage jumps from 12.9 to 19.7 percent. The advantage of continuing marriage over continuing divorce also rises from 9.4 to 12.4 percent. These gains reflect the differences in accumulated work experience associated with marriage. For this reason, the additions to the marriage wage premium are much larger relative to the never-married than to the currently divorced, who may have accumulated added work experience during their married years.

\subsection{Implications for Effects on Men's Earnings}

Using the random effects estimates on wage rates and hours worked, we can illustrate the magnitude of the gains in earnings induced by an additional year of marriage. Consider a man working at $\$ 20$ per hour, about the median wage for full-time workers in 2003 . If he were in a continuing marriage instead of being never-married, his wage rate would rise to $\$ 22.58$ and hours worked would increase by 90 . If hours worked by the never-married were 1800 hours per year, total earnings would rise from $\$ 36,000$ to $\$ 42,676$, or 19 percent of the original earnings level. The feedback effect on wage rates through work experience raises further the full earnings gains from an additional year of marriage. Assuming the small (0.2 percent) wage increment from the feedback effect of added hours worked takes place in each of the next ten years, one can calculate the present value of these additions to earnings and add this component to the marriage earnings premium. The dollar amount of this component turns out to be $\$ 782$, thereby raising the earnings gain from an additional year in marriage from 19 percent to 21 percent. Of the $\$ 7,458$ total earnings gain, we can 
attribute 62 percent to higher wage rates (at initial hours), 24 percent to higher hours worked (at initial wage rates), 10 percent to the feedback effect of hours on future wage rates, and 3 percent to the interaction between higher wage rates and higher hours worked.

Although the marriage earnings advantage is at a maximum when the comparison is between married and single men, the marriage premium remains high when the comparison is with divorced men. Using the same starting point for hours worked and wage rates, remaining married gives men an immediate 16 percent earnings advantage over remaining divorced. Taking account of the indirect effect resulting from the additional marriage-induced work experience raises this premium to about 19 percent. In this case, 50 percent of this overall wage gain is due to higher current wage rates, 33 percent to higher current hours, 14 percent due to the feedback effect, and 3 percent is the interaction component.

These estimates of earnings gains imply a larger role for marriage than most other studies suggest. The main reason is that we take account of the effects of hours worked on current earnings as well as on future wage rates. Looking only at wage rates, we find that our 13 percent marital premium over singles is close to the premiums found by Korneman and Neumark and by Chun and Lee, well below the wage gains found by Antonovics and Town among twins from Minnesota, and well above those reported by Gray and by Cornwall and Rupert. The other studies rely either on data from an earlier cohort (Korneman and Neumark and Cornwall and Rupert), a single cross section (Chun and Lee) or a small population subgroup (Antonovics and Town). Only Gray uses the NLSY79 and his conclusion of a declining marital wage premium is based on only three years of data. We take advantage of over 20 years of NLSY79 data and find marital wage premiums about as large as in earlier cohorts. Further, we estimate separate marital wage effects from entering a first marriage, continuing in marriage, and remarriage. In doing so, we find a large marital wage premium over divorce and sizable wage premium when entering remarriage. 
Among studies taking account of selection effects, this is the first to examine whether the unobserved characteristics affecting both marital flows and wage rates are similar to the unobserved characteristics affecting both marital flows and hours worked. One might expect motivation, reliability, and personality are among the unmeasured attributes influencing wage rates, hours worked, and marriage. On the other hand, some unmeasured attributes may explain higher wages and marriage but not higher hours worked and marriage. To test whether selection in this case represents one or two dimensions of unobserved personal characteristics, we created variables from the individual fixed and random effects derived from the hours worked and log wage equations and examined whether or not they were closely correlated. Somewhat surprisingly, the correlation between the two selection variables was essentially zero, both for random or fixed effects. Thus, there are two dimensions of selection in the wage and hours worked equations.

\subsection{How W age Rates and Accumulated Hours Worked Affect Marital Status}

The long-term decline in the U.S. age-specific marriage rates is an important focus of researchers and policymakers ${ }^{14}$, a trend some attribute to declining male earnings. This section presents new evidence on how wages and hours worked affect the dynamics of marital status. The probit models generating these estimates take account not only of unobserved heterogeneity within the marriage equation but also control for the two dimensions of selection obtained from the hours worked and wage equations.

Table 5 provides three separate estimates of the effects of wage rates and accumulated hours of work on entry into marriage, divorce, and remarriage: probit equations without controls for selection (Model 1), probits with selection controls using random effects (Model 2), and random effects probits that include the selection variables drawn from the hours worked and wage equations (Model 3). The results show higher wage rates increase entry into marriage, discourage entry into 
divorce, and raise the likelihood of remarriage in all three models. Accumulated work experience exerts statistically significant positive impacts on marriage and remarriage, but has no effect on divorce in the models that control for selection.

To illustrate the magnitude of these effects in our preferred model (Model 3), we calculate how 10 percent changes in wage rates and work experience affect the percent change in the probability of the dependent variables. These impacts are evaluated both at the means of other independent variables and at other specified values. The predicted entry rate into marriage using all the coefficients from the random effects probit and the mean values of the independent variables is 5.2 percent. A 10 percent increase in the wage rate raises the entry rate to 5.5 percent, representing a 5.8 percent increase. A 10 percent increase in hours worked has a larger impact, raising the probability of marriage by 6.1 percent.

These magnitudes are generally higher than comparable wage and hours effects on divorce and remarriage. A 10 percent increase wage rates lowered the probability of divorce (among those initially married) by 4.0 percent and raised the probability the probability of remarriage (among those initially divorced or separated) by about 1.7 percent. A 10 percent rise in hours worked had no effect on entry into divorce and raised the entry probabilities into remarriage by 2.7 percent.

One striking result in the marital flow equations is that controlling for selection often strengthens the impacts of wage rates and hours worked. Normally, since unmeasured characteristics that raise wage rates (such as special skills or personality) are expected to be positively correlated with entering marriage and remarriage, estimates of wage impacts that do not control for selection should be biased upward. In fact, comparing Model 2 with Model 1, we find the opposite outcome. Introducing random effect probits to control for selection actually increases the positive impacts of wage rates on marriage and remarriage. It is possible that, for entry into marriage and

\footnotetext{
${ }^{14}$ See Ellwood and Jencks (2004). Also, note that the preamble to the 1996 welfare reform legislation places great
} 
remarriage, selection effects might be negative. Perhaps, some with low unobserved skills are actually more likely to enter marriage or remarriage and thus the estimated wage impact from the baseline probits is biased downward. In Model 3, we include a variable representing the unobserved characteristics that affect wage rates as well as all marital flows. The impact of this variable on entry into marriage is positive and significant, suggesting a positive selection effect. However, the same variable seems to encourage divorce and have no effect on remarriage. Given this mix of findings, some marital flows may involve a negative selection component, in the sense that unmeasured characteristics reduce the likelihood that individual is married.

\subsection{Conclusions and Implications}

With marriage becoming a serious public policy issue, questions arise about the impacts of marriage and about what causes people to marry and stay married. This paper deals with one aspect of both questions_-how does marriage affect men's earnings and how does men's earnings affect marriage? The large, positive association between marriage and earnings is well-known, but the direction of causation and magnitude of the impacts are less clear and quite controversial. Quantifying the effects is difficult because one must control for not only commonly measured variables, such as age, race, educational attainment, academic ability and local employment conditions, but also for unmeasured personal attributes, such as good looks, a positive outlook and a sense of humor which might increase success both in marriage and in the job market.

In trying to answer these questions, we take account of both an extensive set of observed characteristics as well as potential unobserved characteristics. The estimates cover a cohort of young men as they age from 17 to 40, following individuals through all marital status changes over a 23 year period. In addition to estimating the marriage premium on wage rates, we add an analysis of

emphasis on the declining marriage rates in the U.S. as a cause of increased poverty and dependency. 
marriage effects on hours worked. Finally, we examine the impact of experience in the job market and wage rates on entering marriage, divorce, and remarriage.

The findings reveal statistically significant, causal impacts running from marriage to wage rates and working hours, from working hours to subsequent wages, and from both wage rates and working hours to marital status. Putting the wage and hours effects together, we estimate earnings gains of 21 percent caused by entering or remaining married as compared to staying single. The marriage effect relative to divorce remains substantial, at about 19 percent. Even remarriage leads to a 12 percent advantage over those remaining divorced. As expected given our controls for many more observed characteristics and for unobserved factors, these estimates are below the earnings gains derived from the March 2004 CPS cross section. However, marriage effects of these magnitudes are still quite large; they are equivalent to earnings gains associated with 2-3 years of schooling. Far from withering away, as Gray suggests, the marriage wage rate premium remains substantial. $^{15}$

The timing pattern of marriage effects on wage rates and hours worked offers some insight into how the premiums materialize. Upon entering a first marriage, men increase their commitment to work very substantially (160-200 hours per year) but achieve modest wage gains. As men continue in marriage, the marriage increment to hours worked declines, while their wage rate premium increases. As Nock (2005) notes, the institutional nature of marriage may alter how employers treat married relative to unmarried men and what others expect of men, once they marry. A positive signaling effect to employers may lead to an initial wage gain. The domesticating role of marriage for men might help explain the immediate jump in work hours. Because marriage may provide men

\footnotetext{
${ }^{15}$ Gray used the same cohort but only three years of data. When we limit the sample to these years, we also find an insignificant wage rate premium. Blackburn and Korenman (1994) have also suggested that the marriage wage rate premium is declining. They base their estimates on trends in CPS cross sections through 1988, not on panel data.
} 
with greater confidence in their relationship and more ability to specialize, the wage gains associated with marriage may rise over time.

The reverse effects, that success in the labor market raises the likelihood of entering and remaining married and of remarrying, are also statistically significant, especially on entering marriage. The magnitudes of these impacts vary. A 10 percent rise in wage rates increases the likelihood of entering marriage by about 6 percent, the chances of staying married by 4 percent, and remarriage by less than 2 percent. Added hours worked exert about the same effects, except for having no impact on divorce.

What are the implications of these large causal impacts of marriage, wage rates, and hours worked? First, marital status should become more important in the analysis of labor market outcomes and trends. For example, the declining share of married men might well have contributed to the rising earnings inequality and to the stagnancy of wages of less-skilled men. Second, with marriage increasing earnings and earnings leading to more marriage and fewer divorces, policies that lead to marriage and reduce divorce or that raise earnings can set off a virtuous circle, in which marriage and earnings reinforce each other over time. Many unmarried men who appear unable to support a family because of low current earnings are likely to become more adequate breadwinners once they marry. Thus, if proposed programs are able to increase the utility from and appreciation of marriage, they are likely to generate earnings gains for men as an important side effect. 


\section{References}

Antonovics, Kate and Robert Town. 2004. "Are All the Good Men Married? Uncovering the Sources of the Marital Wage Premium.” American Economic Review. May. 317-321.

Ahituv, Avner and Robert Lerman. 2005. "Job Turnover, Wage Rates, and Marital Stability: How Are They Related?” IZA Discussion Paper No. 1470. Bonn, Germany. January.

Becker, Gary S., Elisabeth Landes, and Robert Michael . 1977 "An Economic Analysis of Marital Instability," Journal of Political Economy, 1141-1187.

Blackburn, McKinley and Sanders Korenman. 1994. "The declining marital-status earnings differential." Journal of Population Economics. 7: 247-270.

Burgess, Simon, Carol Propper, and Arnsetin Aassve. 2003. "The role of income in marriage and divorce transitions among young Americans." Journal of Population Economics. 16: 455-475.

Call, Vaughn, and Jay Teachman. 1996. "Life-Course Timing and Sequencing of Marriage and Military Service and Their Effects on Marital Stability." Journal of Marriage and the Family, 58. February. 219-26.

Charles, Kofi and Melvin Stephens, Jr. 2004. "Job Displacement, Disability, and Divorce." Journal of Labor Economics. Vol. 22 (2). 489-522.

Cornwell, Christopher, and Peter Rupert. 1997. Unobservable individual effects, marriage, and the earnings of young men. Economic Inquiry, 35 (April): 285-94.

Chun, Hyunbae and Injae Lee. 2001. "Why Do Married Men Earn More: Productivity or Marriage Selection?" Economic Inquiry. Vol. 39 (2). April. 307-19.

Daniel, Kermit. 1995. "The marriage premium." in The New Economics of Human Behavior. edited by Mariano Tommasi and Kathryn Ierulli, 113-25. Cambridge, England: Cambridge University Press.

Elwood, David and Christopher Jencks. 2004. "The Spread of Single-Parent Families in the United States Since 1960.” In The Future of the Family. edited by Daniel P. Moynihan, Timothy Smeeding, and Lee Rainwater. New York: Russell Sage.

Ginther, Donna and Maqdeline Zavodny. 2001. "Is the Male Marriage Premium Due to Selection? The Effect of Shotgun Weddings on the Return to Marriage." Journal of Population Economics. Vol. 14(2): 313-328.

Goldin, Claudia. 1990. Understanding the Gender Gap: An Economic History of American Women. New York: Oxford University Press.

Gould, Eric and M. Daniele Paserman. 2003. "Waiting for Mr. Right: Rising Inequality and Declining Marriage Rates.” Journal of Urban Economics. Vol. 53(2). 257-281. 
Gray, Jeffrey S. 1996. The fall in men's return to marriage: Declining productivity effects or changing selection? Journal of Human Resources, 32, no. 3: 481-504.

Hersch, Joni and Leslie Stratton. 2000. "Household Specialization and the Male Wage Premium." Industrial and Labor Relations Review. 54 (1). 78-94.

Hotz, V. Joseph, Lixin Xu, Marta Tienda and Avner Ahituv. 2002 "Are There Returns to the Wages of Young Men from Working While in School?" Review of Economics and Statistics, 84(1). (May): 221-236.

Hsiao, Cheng. 1986. Analysis of Panel Data. Cambridge, UK: Cambridge University Press.

Kenny, Lawrence. 1983. "The accumulation of human capital during marriage by males." Economic Inquiry. 21: 223-231.

Korenman, Sanders, and David Neumark. 1991. Does marriage really make men more productive? Journal of Human Resources. 26: 282-307.

Lerman, Robert. 1996. "The Impact of Changing U.S. Family Structure on Child Poverty and Income Inequality." Supplement: Economic Policy and Income Distribution. Economica. 63 (250S): S119-39.

- 2002. "Marriage and the Economic Well-Being of Families with Children: A Review of the Literature.” Urban Institute. Washington, DC. www.urban.org/url.cfm?ID=410541.

Loh, Eng Seng. 1996. "Productivity differences and the marriage premium fore white males." Journal of Human Resources. Vol 31. Issue 3: 566-589.

Loughran, David. 2002. "The Effect of Male Wage Inequality on Female Age at First Marriage." Review of Economics and Statistics. Vol. 84(2): 237-250.

Manning, Wendy D., and Pamela Smock. 1995. "Why Marry? Race and the Transition to Marriage Among Cohabiters." Demography, 32, no. 4, November: 509-20.

New York Times editorial, "Heartless Marriage Plans." The New York Times. January 17, 2004. A14.

Nock, Steven. 2005. "Marriage as a Public Issue." Forthcoming in The Future of Children.

Oppenheimer, Valerie. 2003. "Cohabiting and Marriage During Young Men's Career Development Process." Demography. February. 127-149.

Parsons, Donald. 1977. "Health, Family Structure, and Labor Supply." American Economic Review. Vol. 67 (4): 703-712.

Presser, Harriet. 2000. "Nonstandard Work Schedules and Marital Instability." Journal of Marriage and the Family, 62 (February): 93-110. 
Reed, W. Robert and Kathleen Harford. 1989. "The marriage premium and compensating wage differentials." Journal of Population Economics. 2: 237-265.

Ribar, David. 2003. "What Do Social Scientists Know about the Benefits of Marriage? A Review of Quantitative Methodologies.” Unpublished paper. George Washington University. September.

Schoeni, Robert. 1995. "Marital status and earnings in developed countries." Journal of Population Economics. 8. 351-359.

Smock, Pamela J. and Wendy D. Manning. 1997. "Cohabitation Partners' Economic Circumstances and Marriage.” Demography, Vol. 34, 3:331-341.

Stratton, Leslie. 2002. "Examining the Wage Differential for Married and Cohabiting Men." Economic Inquiry. 40, 2: 199-212.

Teachman, J.D., V.R.A. Call, and K.P. Carver. 1994. "Marital Status and the Duration of Joblessness Among White Men." Journal of Marriage and the Family. Vol. 56, 415-428.

Thomas, Adam and Isabel Sawhill. 2002. "For Richer or Poorer: Marriage as an Antipoverty Strategy." Journal of Policy Analysis and Management. 21 (4). 587-599

Waite, Linda J. and Maggie Gallagher. 2000. The case for marriage. New York: Doubleday.

Weiss, Yoram and Robert J. Willis. 1997. "Match Quality, New Information, and Marital Dissolution.” Journal of Labor Economics. Vol. 15, 1:S293-S329.

Wilson, Chris and Andrew Oswald. 2005. "How Does Marriage Affect Physical and Psychological Health? A Survey of the Longitudinal Evidence." IZA Discussion Paper 1619. Bonn, Germany.

Wilson, William J. 1987. The Truly Disadvantaged. Chicago: University of Chicago Press.

Wood, Robert G. 1995. "Marriage Rates and Marriageable Men: A Test of the Wilson Hypothesis.” Journal of Human Resources. Winter. 163-193. 
Table 1: Marital Transitions of Men from Age 17 to 40 for Cohort Born 1960-1964

Panel A: Annual Marital Status Flows As Percent of All Men, Ages 17 to 40

\begin{tabular}{|c|c|c|c|c|c|c|c|}
\hline Age & $\begin{array}{c}\text { (1) } \\
\text { From Single } \\
\text { to Single } \\
\end{array}$ & $\begin{array}{c}(2) \\
\text { From Single } \\
\text { to First } \\
\text { Marriage } \\
\end{array}$ & $\begin{array}{c}(3) \\
\text { From Marriage } \\
\text { (or Remarriage) } \\
\text { to Marriage } \\
\end{array}$ & $\begin{array}{c}(4) \\
\text { From Marriage } \\
\text { (or Remarriage) } \\
\text { to Divorce } \\
\end{array}$ & $\begin{array}{c}(5) \\
\text { From } \\
\text { Divorce to } \\
\text { Divorce } \\
\end{array}$ & $\begin{array}{c}(6) \\
\text { From } \\
\text { Divorce to } \\
\text { Remarriage }\end{array}$ & $\begin{array}{c}(7) \\
\text { Share in } \\
\text { First } \\
\text { Marriages }\end{array}$ \\
\hline 17 & 99.4 & 0.6 & 0.0 & 0.0 & 0.0 & 0.0 & 0.6 \\
\hline 18 & 97.5 & 2.1 & 0.4 & 0.1 & 0.0 & 0.0 & 2.5 \\
\hline 19 & 93.7 & 4.3 & 1.9 & 0.1 & 0.0 & 0.0 & 6.2 \\
\hline 20 & 87.9 & 5.7 & 5.6 & 0.7 & 0.1 & 0.0 & 11.3 \\
\hline 21 & 83.0 & 5.1 & 10.0 & 1.3 & 0.7 & 0.1 & 15.0 \\
\hline 22 & 76.8 & 6.2 & 13.7 & 1.5 & 1.5 & 0.4 & 19.8 \\
\hline 23 & 68.8 & 8.2 & 18.5 & 1.6 & 2.3 & 0.6 & 26.2 \\
\hline 24 & 61.9 & 7.1 & 25.3 & 1.9 & 3.2 & 0.6 & 31.4 \\
\hline 25 & 54.7 & 7.3 & 31.0 & 2.1 & 4.2 & 0.8 & 36.9 \\
\hline 26 & 48.6 & 6.1 & 36.8 & 2.4 & 5.2 & 1.0 & 40.9 \\
\hline 27 & 44.0 & 4.6 & 41.1 & 2.6 & 6.4 & 1.4 & 43.3 \\
\hline 28 & 40.2 & 3.9 & 44.3 & 2.8 & 7.4 & 1.4 & 44.6 \\
\hline 29 & 36.6 & 4.1 & 46.9 & 2.3 & 8.7 & 1.4 & 46.5 \\
\hline 30 & 33.9 & 2.7 & 49.8 & 2.4 & 9.6 & 1.6 & 47.1 \\
\hline 31 & 31.6 & 2.2 & 52.1 & 2.2 & 10.9 & 1.1 & 47.9 \\
\hline 32 & 29.0 & 2.5 & 53.7 & 1.8 & 11.7 & 1.3 & 49.4 \\
\hline 33 & 27.0 & 1.6 & 55.6 & 2.3 & 12.3 & 1.3 & 49.6 \\
\hline 34 & 25.3 & 1.8 & 56.6 & 1.8 & 12.7 & 1.8 & 50.0 \\
\hline 35 & 23.9 & 1.6 & 58.4 & 1.7 & 13.4 & 1.1 & 50.4 \\
\hline 36 & 22.8 & 1.2 & 59.0 & 2.2 & 13.6 & 1.3 & 50.3 \\
\hline 37 & 21.6 & 1.3 & 59.2 & 2.2 & 14.0 & 1.8 & 49.8 \\
\hline 38 & 19.9 & 1.4 & 60.4 & 2.2 & 14.7 & 1.4 & 50.2 \\
\hline 39 & 19.1 & 0.3 & 61.4 & 1.6 & 15.8 & 1.8 & 50.2 \\
\hline 40 & 17.7 & 0.4 & 63.3 & 1.6 & 15.1 & 1.9 & 50.7 \\
\hline
\end{tabular}

Panel B: Annual Marital Status Flows As Percent of Men in the Risk Group

\begin{tabular}{cccc}
\hline \hline Age & $\begin{array}{c}\text { Entry Into First Marriage } \\
\text { from Never-Married }\end{array}$ & $\begin{array}{c}\text { Entry Into Divorce from Marriage } \\
\text { or Remarriage }\end{array}$ & $\begin{array}{c}\text { Entry Into Remarriage } \\
\text { from Divorce }\end{array}$ \\
\hline $20-22$ & $6.9 \%$ & $12.1 \%$ & $42.7 \%$ \\
$23-25$ & $12.2 \%$ & $7.5 \%$ & $21.1 \%$ \\
$26-28$ & $10.9 \%$ & $6.4 \%$ & $19.8 \%$ \\
$29-31$ & $8.7 \%$ & $4.6 \%$ & $14.0 \%$ \\
$32-34$ & $7.2 \%$ & $3.6 \%$ & $11.8 \%$ \\
$35-37$ & $5.9 \%$ & $3.4 \%$ & $10.0 \%$ \\
$38-40$ & $3.6 \%$ & $3.0 \%$ & $11.1 \%$ \\
\hline
\end{tabular}

Source: Tabulations by authors from the NLSY79 sample of 2,863 males described in the text. The data are weighted to correct for the oversampling of black and Hispanic respondents. 
Table 2: Work Outcomes by Age and Marital Status for 1960-1962 Cohort

Panel A: Hourly Wage (in 1985 \$), Ratios to Single Men in Parentheses

\begin{tabular}{|c|c|c|c|c|c|c|c|c|}
\hline \multirow[b]{2}{*}{ Age } & \multicolumn{4}{|c|}{ Full Sample } & \multicolumn{4}{|c|}{ Black Men } \\
\hline & Single & Married & Divorced & Remarried & Single & Married & Divorced & Remarried \\
\hline 20 & $\begin{array}{l}\$ 5.56 \\
(1.00)\end{array}$ & $\begin{array}{l}\$ 6.66 \\
(1.20)\end{array}$ & $\begin{array}{l}\$ 5.08 \\
(0.91)\end{array}$ & na & $\begin{array}{l}\$ 4.66 \\
(1.00)\end{array}$ & $\begin{array}{l}\$ 5.53 \\
(1.19)\end{array}$ & $\begin{array}{l}\$ 3.60 \\
(0.77)\end{array}$ & na \\
\hline 24 & $\begin{array}{c}6.86 \\
(1.00)\end{array}$ & $\begin{array}{c}7.52 \\
(1.10)\end{array}$ & $\begin{array}{c}7.08 \\
(1.03)\end{array}$ & $\begin{array}{c}7.66 \\
(1.12)\end{array}$ & $\begin{array}{c}5.61 \\
(1.00)\end{array}$ & $\begin{array}{c}6.17 \\
(1.10)\end{array}$ & $\begin{array}{c}7.39 \\
(1.32)\end{array}$ & $\begin{array}{c}2.51 \\
(0.45)\end{array}$ \\
\hline 28 & $\begin{array}{c}8.55 \\
(1.00)\end{array}$ & $\begin{array}{l}10.12 \\
(1.18)\end{array}$ & $\begin{array}{c}8.20 \\
(0.96)\end{array}$ & $\begin{array}{l}11.61 \\
(1.36)\end{array}$ & $\begin{array}{c}6.52 \\
(1.00)\end{array}$ & $\begin{array}{c}7.19 \\
(1.10)\end{array}$ & $\begin{array}{c}6.98 \\
(1.07)\end{array}$ & $\begin{array}{c}6.31 \\
(0.97)\end{array}$ \\
\hline 32 & $\begin{array}{c}8.74 \\
(1.00)\end{array}$ & $\begin{array}{l}10.48 \\
(1.20)\end{array}$ & $\begin{array}{c}7.10 \\
(0.81)\end{array}$ & $\begin{array}{c}9.88 \\
(1.13)\end{array}$ & $\begin{array}{c}6.55 \\
(1.00)\end{array}$ & $\begin{array}{c}8.58 \\
(1.31)\end{array}$ & $\begin{array}{c}5.57 \\
(0.85)\end{array}$ & $\begin{array}{c}7.62 \\
(1.16)\end{array}$ \\
\hline 36 & $\begin{array}{c}9.26 \\
(1.00)\end{array}$ & $\begin{array}{l}12.61 \\
(1.36)\end{array}$ & $\begin{array}{c}9.07 \\
(0.98)\end{array}$ & $\begin{array}{l}10.41 \\
(1.12)\end{array}$ & $\begin{array}{c}6.17 \\
(1.00)\end{array}$ & $\begin{array}{c}9.01 \\
(1.46)\end{array}$ & $\begin{array}{c}8.24 \\
(1.34)\end{array}$ & $\begin{array}{c}8.66 \\
(1.40)\end{array}$ \\
\hline 40 & $\begin{array}{l}11.05 \\
(1.00) \\
\end{array}$ & $\begin{array}{l}16.38 \\
(1.48) \\
\end{array}$ & $\begin{array}{c}9.48 \\
(0.86)\end{array}$ & $\begin{array}{l}10.85 \\
(0.98)\end{array}$ & $\begin{array}{c}6.28 \\
(1.00) \\
\end{array}$ & $\begin{array}{r}9.77 \\
(1.55) \\
\end{array}$ & $\begin{array}{r}8.41 \\
(1.34) \\
\end{array}$ & $\begin{array}{r}9.30 \\
(1.48) \\
\end{array}$ \\
\hline
\end{tabular}

Panel B: Hours Worked in Prior Year, Ratios to Single Men in Parentheses

\begin{tabular}{|c|c|c|c|c|c|c|c|c|}
\hline \multirow[b]{2}{*}{ Age } & \multicolumn{4}{|c|}{ Full Sample } & \multicolumn{4}{|c|}{ Black Men } \\
\hline & Single & Married & Divorced & Remarried & Single & Married & Divorced & Remarried \\
\hline 20 & $\begin{array}{l}1,282 \\
(1.00)\end{array}$ & $\begin{array}{l}1,978 \\
(1.54)\end{array}$ & $\begin{array}{l}1,260 \\
(0.98)\end{array}$ & na & $\begin{array}{c}998 \\
(1.00)\end{array}$ & $\begin{array}{l}1,683 \\
(1.69)\end{array}$ & $\begin{array}{l}1,225 \\
(1.23)\end{array}$ & na \\
\hline 24 & $\begin{array}{l}1,712 \\
(1.00)\end{array}$ & $\begin{array}{l}2,101 \\
(1.23)\end{array}$ & $\begin{array}{l}1,954 \\
(1.14)\end{array}$ & $\begin{array}{l}2,196 \\
(1.28)\end{array}$ & $\begin{array}{l}1,382 \\
(1.00)\end{array}$ & $\begin{array}{l}1,779 \\
(1.29)\end{array}$ & $\begin{array}{l}1,645 \\
(1.19)\end{array}$ & $\begin{array}{l}1,880 \\
(1.36)\end{array}$ \\
\hline 28 & $\begin{array}{l}1,892 \\
(1.00)\end{array}$ & $\begin{array}{l}2,238 \\
(1.18)\end{array}$ & $\begin{array}{l}1,994 \\
(1.05)\end{array}$ & $\begin{array}{l}2,271 \\
(1.20)\end{array}$ & $\begin{array}{l}1,467 \\
(1.00)\end{array}$ & $\begin{array}{l}2,072 \\
(1.41)\end{array}$ & $\begin{array}{l}1,700 \\
(1.16)\end{array}$ & $\begin{array}{l}2,321 \\
(1.58)\end{array}$ \\
\hline 32 & $\begin{array}{l}1,783 \\
(1.00)\end{array}$ & $\begin{array}{l}2,306 \\
(1.29)\end{array}$ & $\begin{array}{l}1,962 \\
(1.10)\end{array}$ & $\begin{array}{l}2,098 \\
(1.18)\end{array}$ & $\begin{array}{l}1,334 \\
(1.00)\end{array}$ & $\begin{array}{l}2,027 \\
(1.52)\end{array}$ & $\begin{array}{l}1,657 \\
(1.24)\end{array}$ & $\begin{array}{l}1,818 \\
(1.36)\end{array}$ \\
\hline 36 & $\begin{array}{l}1,887 \\
(1.00)\end{array}$ & $\begin{array}{l}2,303 \\
(1.22)\end{array}$ & $\begin{array}{l}2,047 \\
(1.08)\end{array}$ & $\begin{array}{l}2,160 \\
(1.14)\end{array}$ & $\begin{array}{l}1,468 \\
(1.00)\end{array}$ & $\begin{array}{l}2,134 \\
(1.45)\end{array}$ & $\begin{array}{l}1,669 \\
(1.14)\end{array}$ & $\begin{array}{l}1,942 \\
(1.32)\end{array}$ \\
\hline 40 & $\begin{array}{l}1,720 \\
(1.00)\end{array}$ & $\begin{array}{l}2,282 \\
(1.33)\end{array}$ & $\begin{array}{l}2,003 \\
(1.16)\end{array}$ & $\begin{array}{l}2,134 \\
(1.24)\end{array}$ & $\begin{array}{l}1,285 \\
(1.00)\end{array}$ & $\begin{array}{l}2,124 \\
(1.65)\end{array}$ & $\begin{array}{l}1,689 \\
(1.31)\end{array}$ & $\begin{array}{l}1,886 \\
(1.47)\end{array}$ \\
\hline
\end{tabular}

Source: Tabulations by authors from the NLSY79 sample of 1,446 males born in 1960-62. The data are weighted to correct for the oversampling of black and Hispanic respondents.. 
Table 3: The Effects of Marital Flows on Annual Hours Worked

Panel A: Comparisons Across Econometric Specifications

\begin{tabular}{|c|c|c|c|}
\hline & $\begin{array}{c}(1) \\
\text { OLS }\end{array}$ & $\begin{array}{c}(2) \\
\text { Fixed Effects }\end{array}$ & $\begin{array}{c}\text { (3) } \\
\text { Random Effects }\end{array}$ \\
\hline Entry into first marriage & $\begin{array}{c}262.0 \\
(16.89)^{* *}\end{array}$ & $\begin{array}{c}160.3 \\
(10.79)^{* *}\end{array}$ & $\begin{array}{c}200.5 \\
(13.67)^{* *}\end{array}$ \\
\hline Continuing marriage & $\begin{array}{c}155.0 \\
(18.14)^{* *}\end{array}$ & $\begin{array}{c}51.6 \\
(4.78)^{* *}\end{array}$ & $\begin{array}{c}89.6 \\
(9.05)^{* *}\end{array}$ \\
\hline Entry into divorce & $\begin{array}{c}114.8 \\
(5.35)^{* *}\end{array}$ & $\begin{array}{c}38.0 \\
(1.78)\end{array}$ & $\begin{array}{c}68.8 \\
(3.31)^{* *}\end{array}$ \\
\hline Continuing divorce & $\begin{array}{c}10.1 \\
(0.85)\end{array}$ & $\begin{array}{c}-51.3 \\
(3.38)^{* *}\end{array}$ & $\begin{array}{l}-20.7 \\
(1.49)\end{array}$ \\
\hline Entry into remarriage & $\begin{array}{c}146.5 \\
(5.07)^{* *}\end{array}$ & $\begin{array}{c}37.3 \\
(1.33)\end{array}$ & $\begin{array}{c}78.3 \\
(2.83)^{* *}\end{array}$ \\
\hline Lag of Log of Hourly Pay & $\begin{array}{c}16.4 \\
(2.89)^{* *}\end{array}$ & $\begin{array}{c}-6.1 \\
(0.96) \\
\end{array}$ & $\begin{array}{c}1.3 \\
(0.22) \\
\end{array}$ \\
\hline \multicolumn{4}{|c|}{ Panel B: Comparisons Across Specific Subgroups } \\
\hline & $\begin{array}{c}(4) \\
\text { Black }\end{array}$ & $\begin{array}{c}(5) \\
\text { Low AFQT }\end{array}$ & $\begin{array}{c}\text { (6) } \\
\text { Under } 30 \\
\end{array}$ \\
\hline Entry into first marriage & $\begin{array}{c}256.5 \\
(7.97)^{* *}\end{array}$ & $\begin{array}{c}249.4 \\
(7.68)^{* *}\end{array}$ & $\begin{array}{c}174.6 \\
(11.18)^{* *}\end{array}$ \\
\hline Continuing marriage & $\begin{array}{c}60.3 \\
(3.14)^{* *}\end{array}$ & $\begin{array}{c}97.6 \\
(4.73)^{* *}\end{array}$ & $\begin{array}{c}119.0 \\
(9.46)^{* *}\end{array}$ \\
\hline Entry into divorce & $\begin{array}{c}3.6 \\
(0.09)\end{array}$ & $\begin{array}{c}25.9 \\
(0.65)\end{array}$ & $\begin{array}{c}72.4 \\
(2.66)^{* *}\end{array}$ \\
\hline Continuing divorce & $\begin{array}{c}-72.3 \\
(2.86)^{* *}\end{array}$ & $\begin{array}{l}-30.5 \\
(1.19)\end{array}$ & $\begin{array}{c}-79.1 \\
(3.58)^{* *}\end{array}$ \\
\hline Entry into remarriage & $\begin{array}{l}-25.2 \\
(0.41)\end{array}$ & $\begin{array}{l}101.2 \\
(1.86)^{*}\end{array}$ & $\begin{array}{c}50.5 \\
(1.18)\end{array}$ \\
\hline Lag of Log of Hourly Pay & $\begin{array}{c}10.0 \\
(0.84)\end{array}$ & $\begin{array}{l}-24.7 \\
(1.97)^{*}\end{array}$ & $\begin{array}{c}43.6 \\
(5.62)^{* *}\end{array}$ \\
\hline
\end{tabular}

Notes: The other variables included in the regressions, are reported in Appendix B-2. The absolute values of $t$-statistics are reported in parentheses. ${ }^{*}$ significant at $5 \%$ level, and $* *$ significant at $1 \%$ level 
Table 4: The Effect of Marital Flows on Ln of Hourly Wage Rates

Panel A: Comparing Across Econometric Specifications

\begin{tabular}{|c|c|c|c|}
\hline & $\begin{array}{c}(1) \\
\text { OLS }\end{array}$ & $\begin{array}{c}\text { (2) } \\
\text { Fixed Effects }\end{array}$ & $\begin{array}{c}\text { (3) } \\
\text { Random Effects }\end{array}$ \\
\hline \multirow[t]{2}{*}{ Entry into first marriage } & 0.118 & 0.076 & 0.085 \\
\hline & $(10.77)^{* *}$ & $(7.92)^{* *}$ & $(8.89)^{* *}$ \\
\hline \multirow[t]{2}{*}{ Continuing marriage } & 0.175 & 0.119 & 0.129 \\
\hline & $(32.28) * *$ & $(18.09)^{* *}$ & $(20.76)^{* *}$ \\
\hline \multirow[t]{2}{*}{ Entry into divorce } & 0.106 & 0.066 & 0.074 \\
\hline & $(7.03)^{* *}$ & $(4.86)^{* *}$ & $(5.52)^{* *}$ \\
\hline \multirow[t]{2}{*}{ Continuing divorce } & 0.057 & 0.029 & 0.035 \\
\hline & $(7.02)^{* *}$ & $(2.95) * *$ & $(3.82)^{* *}$ \\
\hline \multirow[t]{2}{*}{ Entry into remarriage } & 0.119 & 0.071 & 0.08 \\
\hline & $(5.87)^{* *}$ & $(3.95)^{* *}$ & $(4.46)^{* *}$ \\
\hline \multirow[t]{2}{*}{ Work Experience (hours) } & 0.024 & 0.024 & 0.023 \\
\hline & $(31.11)^{* *}$ & $(25.65)^{* *}$ & $(26.81)^{* *}$ \\
\hline \multirow[t]{2}{*}{ Experience squared } & 0.000 & 0.000 & 0.000 \\
\hline & $(16.37)^{* *}$ & $(13.81)^{* *}$ & $(14.09)^{* *}$ \\
\hline \multicolumn{4}{|c|}{ Panel B: Comparisons Across Specific Subgroups } \\
\hline & (4) & $(5)$ & $(6)$ \\
\hline & Black & Low AFQT & Without Hours \\
\hline \multirow[t]{2}{*}{ Entry into first marriage } & 0.094 & 0.07 & 0.097 \\
\hline & $(4.71) * *$ & $(3.55)^{* *}$ & $(10.03)^{* *}$ \\
\hline \multirow[t]{2}{*}{ Continuing marriage } & 0.133 & 0.109 & 0.197 \\
\hline & $(10.82)^{* *}$ & $(8.66)^{* *}$ & $(32.40)^{* *}$ \\
\hline \multirow[t]{2}{*}{ Entry into divorce } & 0.096 & 0.100 & 0.124 \\
\hline & $(3.75)^{* *}$ & $(4.11)^{* *}$ & $(9.09)^{* *}$ \\
\hline \multirow[t]{2}{*}{ Continuing divorce } & 0.061 & 0.089 & 0.073 \\
\hline & $(3.66)^{* *}$ & $(5.46)^{* *}$ & $(7.93)^{* *}$ \\
\hline \multirow[t]{2}{*}{ Entry into remarriage } & 0.123 & 0.158 & 0.137 \\
\hline & $(3.28) * *$ & $(4.79)^{* *}$ & $(7.56)^{* *}$ \\
\hline \multirow[t]{2}{*}{ Work Experience (hours) } & 0.016 & 0.015 & \\
\hline & $(9.73)^{* *}$ & $(9.29)^{* *}$ & \\
\hline \multirow[t]{2}{*}{ Experience squared } & 0.000 & 0.000 & \\
\hline & $(3.68)^{* *}$ & $(5.03) * *$ & \\
\hline
\end{tabular}

Notes: The other variables included in the regressions, are reported in Appendix B-3. The absolute values of t-statistics are reported in parentheses. ${ }^{*}$ signal significant at $5 \%$ level, and $* *$ significant at $1 \%$ level 
Table 5: The Effects of Wage Rates and Work Experience on Entry into Marriage, Divorce, and Remarriage

Panel A: Entry into First Marriage

\begin{tabular}{lccc}
\hline \hline & $(1)$ & $\begin{array}{c}(2) \\
\text { Probit with } \\
\text { Random Effects }\end{array}$ & $\begin{array}{c}(3) \\
\text { Random Effects } \\
\text { and Factors }\end{array}$ \\
\hline $\begin{array}{l}\text { Work Experience (accumulated } \\
\text { hours) }\end{array}$ & 0.038 & 0.065 & 0.049 \\
Experience squared & $(7.5)$ & $(7.3)$ & $(5.9)$ \\
& -0.0004 & -0.0005 & -0.0004 \\
Lag of Log of Hourly Pay & $(3.8)$ & $(3.1)$ & $(2.8)$ \\
& 0.242 & 0.308 & 0.267 \\
Fixed Error Component from & $(11.3)$ & $(9.6)$ & $(8.0)$ \\
Hours Equation & & & 0.0006 \\
Fixed Error Component from & & & $(7.8)$ \\
Wage Equation & & & 0.223 \\
& & & $(2.5)$ \\
\hline
\end{tabular}

Panel B: Entry into Divorce

\begin{tabular}{lccc}
\hline Work Experience (accumulated & -0.0147 & -0.0141 & -0.007 \\
hours) & $(2.4)$ & $(2.1)$ & $(0.9)$ \\
Experience squared & 0.0001 & 0.0000 & 0.0000 \\
& $(0.9)$ & $(0.7)$ & $(0.7)$ \\
Lag of Log of Hourly Pay & -0.141 & -0.142 & -0.185 \\
& $(4.3)$ & $(3.9)$ & $(4.2)$ \\
Fixed Error Component from & & & -0.0002 \\
Hours Equation & & & $(4.0)$ \\
Fixed Error Component from & & & 0.127 \\
Wage Equation & & $(1.6)$ \\
\hline
\end{tabular}

Panel C: Entry into Remarriage

\begin{tabular}{lccc}
\hline Work Experience (accumulated & 0.027 & 0.028 & 0.023 \\
hours) & $(2.9)$ & $(2.9)$ & $(2.3)$ \\
Experience squared & -0.0002 & -0.0002 & -0.0002 \\
& $(1.5)$ & $(1.5)$ & $(1.5)$ \\
Lag of Log of Hourly Pay & 0.101 & 0.103 & 0.094 \\
& $(2.2)$ & $(2.7)$ & $(1.6)$ \\
Fixed Error Component from & & & 0.0002 \\
Hours Equation & & & $(2.4)$ \\
Fixed Error Component from & & & 0.031 \\
Wage Equation & & & $(0.3)$ \\
\hline
\end{tabular}

Notes: Absolute value of t-statistics in parentheses;

The regressions in Panel A includes 2,863 individuals and 33,842 observations;

The regressions in Panel B includes 2,091 individuals and 21,915 observations;

The regressions in Panel C includes864 individuals and 5,477 observations; 


\section{Appendix A: Filling in Information for Post-1994 Non-Interview Years}

This analysis uses the NLSY79 from 1979 to 2002. Hence, we have to adjust the data after 1994 (when the NLSY79 conducted only biannual interviews). Fortunately, the NLSY includes work-history array on a weekly basis that allowing recovering information on all job related variables, and good information on dates of marital statuses changes, and birth. We could not calculate comparable information for schooling and location variables. Below we explain how we construct the key variables of our analysis.

The NLSY79 work-history includes variables on work activities (including hours worked, job change, and wage) for each week of the 1,304 weeks, starting from January 1978 to December 2002. To obtain the correct number of hours worked or weeks worked in each calendar year, we simply looped through each of the 52 weeks and calculated a running sum.

Prior to 1994, hourly wage and job tenure are those reported for the current job. For those men that are not employed during the interview week, the primary job is the longest job in the year prior to the interview week. The wage is the last hourly wage earned on this job, and job tenure is zero. For the odd-post-1994 years, we use the following method. First, we designate a "quasiinterview" week, exactly 52 weeks prior to the actual interview week in the subsequent year. Second, we code the start and end weeks for each job. Third, we determine hourly wage and job tenure for the odd (post-1994 years) similarly to the method describes above.

The NLSY reports the exact date of each change in marital status. Again, we linked the change in marital status to the dates of the most recent interview, and to the date of the "quasiinterview". Those events taking place within 52 weeks prior to the interview week were current year transitions. If the transitions occurred more than 52 weeks before the even-year interview, then we coded that change as having occurred in the odd-year. 
For the following variables, we could not record changes in the odd-post-1994 years. County of residence (say, in 1999) was set equal to the county where the individual lived in the subsequent even-year (say, 2000). Once we specified the county of residence for the odd-post-1994 year (say, 1999), we used the relevant year's (say, 1999) information on county variables, such as county employment growth and unemployment rates. For highest grade completed in the odd-post-1994 years, we used the grade achieved as of the subsequent even-year. If the difference between two even post-1994 year (say, 1996 and 1998) is two, we set the odd year to the mean between the two years (total of only 90 cases). Note that at the ages reached by cohort members after 1994, only 450 observations-years are in school. 


\section{DEPENDENT AND ENDOGENOUS VARIABLES}

Marital Status

Marital status of R: single, new marriage, cont. marriage, new divorce, cont. divorce, new remarriage

Ln of Hourly Wage Rate

Ln of Hourly Wage Rate

Annual Hours Work

Annual Hours Work, cap at 3,120

1,731

\section{SELECTED INDEPENDENT VARIABLES}

\section{Ascribed Traits and Scholastic Aptitude (X)}

Age

Black

Hispanic

Foreign

AFQT

\section{Family Background (X)}

Family Income

Mother's Education

Number of Siblings

Female-Headed Household
Age at the beginning of the year

Dummy variable indicating African American

Dummy variable indicating Hispanic

0.20

Dummy variable indicating Foreign born $\quad 0.07$

Armed Forces Qualify Test score

(Age and scale adjusted to 1,10 interval)

Total annual family income in $1979(\$ 1,000,000)$

Highest grade completed (in years) by R's mother

10.94

Number of living siblings in 1979

3.79

Dummy, $\mathrm{R}$ lived in a female-headed household at age 14

\section{Social Affiliation and Pre-work Experience (X)}

Illegal Activities

Baptists Religion

Catholic Religion

Frequency of Church Att.

Highest grade completed

In School

GED
Had any illegal activity by age 17

0.14

Self response as practice Baptists religion

0.27

Self response as practice Catholic religion

0.35

Frequency of religious attending in 1979

(6 points scale, with 6 as highest)

Highest grade comp. through the beginning of this year

12.48

Attending school at the Interview date

0.17

Received GED 


\section{Local Market Conditions (X)}

Resident in Urban area

$\mathrm{R}$. is presently resident in Urban area

County Average Earnings

Average earnings per job, county of residence $(\$ 1,000)$

County Empl. Growth

Percent employment growth in R's county of residence

0.02

County Unemployment Rate

Unemployment Rate in R's county of residence

County Marriage Rate

Marriage rates per 1,000, County of residence

10.13

County Divorce Rate

Divorces rates per Marriages, County of residence

\section{Work Experience and Education Indicators $(Z, W, H)$}

Work Experience

Accumulated Hours

Number of Jobs

Tenure

Ln wage prior year
Weeks (divided by 52) worked from age 17 to this year

Total hours worked (in 1,000) from age 17 to this year

Total number of jobs ever reported

7.96

Tenure with current employer (weeks divided by 52)

3.16

Lag of Hourly Wage Rate from prior year

\section{Marital and Family Statuses (MS)}

New Marriage

Continuing Marriage

New Divorce or Separation

Continuing Divorce or

Separation

New Remarriage

One or Two Child

Three or more children

Spouse Grade
Those who married for the first time during this calendar year

Those who continue to be married in the current year (including second marriages)

Those who divorced or separated during this year

Those who continue to be divorced or separated

during the current year

Those who remarried during this calendar year 0.01

Has one or two children at the beginning of this year $\quad 0.35$

Has three or more children at the beginning of this year 0.12

Spouse Grade, just if spouse exists 
Appendix Table B-2: Determinants of Annual Hours Worked: All Independent Variables

\begin{tabular}{|c|c|c|c|c|c|c|}
\hline & $\begin{array}{c}(1) \\
\text { OLS }\end{array}$ & $\begin{array}{c}(2) \\
\text { Fixed Effects }\end{array}$ & $\begin{array}{c}\text { (3) } \\
\text { Random Effects }\end{array}$ & $\begin{array}{c}(4) \\
\text { Black }\end{array}$ & $\begin{array}{c}\text { (5) } \\
\text { Low AFQT }\end{array}$ & $\begin{array}{c}(6) \\
\text { Under 30 }\end{array}$ \\
\hline \multirow[t]{2}{*}{ Entry into first marriage } & 262.0 & 160.3 & 200.5 & 256.5 & 249.4 & 174.6 \\
\hline & $(16.89)^{* *}$ & $(10.79)^{* *}$ & $(13.67)^{* *}$ & $(7.97) * *$ & $(7.68)^{* *}$ & $(11.18)^{* *}$ \\
\hline \multirow[t]{2}{*}{ Continuing marriage } & 155.0 & 51.6 & 89.6 & 60.3 & 97.6 & 119.0 \\
\hline & $(18.14)^{* *}$ & $(4.78)^{* *}$ & $(9.05) * *$ & $(3.14)^{* *}$ & $(4.73)^{* *}$ & $(9.46)^{* *}$ \\
\hline \multirow[t]{2}{*}{ Entry into divorce } & 114.8 & 38.0 & 68.8 & 3.6 & 25.9 & 72.4 \\
\hline & $(5.35)^{* *}$ & $(1.78)$ & $(3.31)^{* *}$ & $(0.09)$ & $(0.65)$ & $(2.66) * *$ \\
\hline \multirow[t]{2}{*}{ Continuing divorce } & 10.1 & -51.3 & -20.7 & -72.3 & -30.5 & -79.1 \\
\hline & $(0.85)$ & $(3.38)^{* *}$ & $(1.49)$ & $(2.86)^{* *}$ & $(1.19)$ & $(3.58)^{* *}$ \\
\hline \multirow[t]{2}{*}{ Entry into remarriage } & 146.5 & 37.3 & 78.3 & -25.2 & 101.2 & 50.5 \\
\hline & $(5.07) * *$ & $(1.33)$ & $(2.83)^{* *}$ & $(0.41)$ & $(1.86)^{*}$ & $(1.18)$ \\
\hline Lag of Log of Hourly & 16.4 & -6.1 & 1.3 & 10.0 & -24.7 & 43.6 \\
\hline Pay & $(2.89)^{* *}$ & $(0.96)$ & $(0.22)$ & $(0.84)$ & $(1.97)^{*}$ & $(5.62)^{* *}$ \\
\hline \multirow[t]{2}{*}{ Age } & -128.4 & -150.6 & -148.1 & -159.0 & -134.1 & -253.6 \\
\hline & $(21.30)^{* *}$ & $(22.73)^{* *}$ & $(24.14)^{* *}$ & $(14.46)^{* *}$ & $(11.85)^{* *}$ & $(15.19)^{* *}$ \\
\hline \multirow{2}{*}{ Age Squared } & 0.8 & 1.4 & 1.2 & 1.3 & 0.9 & 3.3 \\
\hline & $(7.76)^{* *}$ & $(13.33)^{* *}$ & $(12.53)^{* *}$ & $(7.31)^{* *}$ & $(5.00)^{* *}$ & $(9.41)^{* *}$ \\
\hline \multirow[t]{2}{*}{ Black } & -98.6 & & -160.4 & & -123.2 & -131.3 \\
\hline & $(12.24)^{* *}$ & & $(10.27)^{* *}$ & & $(4.07)^{* *}$ & $(8.20)^{* *}$ \\
\hline \multirow[t]{2}{*}{ Hispanic } & -25.0 & & -35.1 & & -51.7 & -36.5 \\
\hline & $(2.92)^{* *}$ & & $(2.09)^{*}$ & & $(1.43)$ & $(2.13)^{*}$ \\
\hline \multirow[t]{2}{*}{ Foreign Born } & 45.4 & & 51.8 & & 97.4 & 41.4 \\
\hline & $(3.92)^{* *}$ & & $(2.24)^{*}$ & & $(2.17)^{*}$ & $(1.76)^{*}$ \\
\hline \multirow[t]{2}{*}{ AFQT } & -3.2 & & -16.2 & -13.0 & 74.1 & -20.1 \\
\hline & -1.83 & & $(5.00)^{* *}$ & $(1.77)^{*}$ & $(1.79)^{*}$ & $(6.08)^{* *}$ \\
\hline \multirow[t]{2}{*}{ Family Income, 1979} & 1041.9 & & 678.5 & 112.0 & -461.4 & 928.1 \\
\hline & $(5.57)^{* *}$ & & $(1.80)^{*}$ & $(0.14)$ & -0.38 & $(2.42)^{* *}$ \\
\hline \multirow[t]{2}{*}{ Missing Family Income } & 60.7 & & 56.2 & 64.3 & 42.6 & 67.2 \\
\hline & $(7.40)^{* *}$ & & $(3.41)^{* *}$ & $(2.37) * *$ & $(1.32)$ & $(4.01)^{* *}$ \\
\hline \multirow[t]{2}{*}{ Illegal } & -60.8 & & -80.9 & -58.8 & -89.1 & -77.2 \\
\hline & $(7.30)^{* *}$ & & $(4.89)^{* *}$ & $(2.02)^{*}$ & $(3.04)^{* *}$ & $(4.56)^{* *}$ \\
\hline \multirow[t]{2}{*}{ Work Experience (weeks) } & 237.8 & 212.6 & 230.9 & 253.6 & 235.9 & 393.4 \\
\hline & $(87.15)^{* *}$ & $(54.67)^{* *}$ & $(70.23)^{* *}$ & $(42.67)^{* *}$ & $(37.78) * *$ & $(66.34)^{* *}$ \\
\hline \multirow[t]{2}{*}{ Experience squared } & -6.2 & -6.3 & -6.6 & -7.7 & -7.1 & -21.7 \\
\hline & $(51.44)^{* *}$ & $(47.27)^{* *}$ & $(53.00)^{* *}$ & $(31.33)^{* *}$ & $(27.33)^{* *}$ & $(51.01)^{* *}$ \\
\hline \multirow[t]{2}{*}{ Job Tenure } & 36.0 & 41.8 & 39.5 & 62.4 & 65.0 & 78.9 \\
\hline & $(38.99)^{* *}$ & $(38.88)^{* *}$ & $(38.93)^{* *}$ & $(27.50)^{* *}$ & $(26.50)^{* *}$ & $(35.76)^{* *}$ \\
\hline Number of Jobs & 9.8 & 24.7 & 16.7 & 23.6 & 27.4 & 23.3 \\
\hline & $(14.70)^{* *}$ & $(19.46)^{* *}$ & $(17.08)^{* *}$ & $(12.37)^{* *}$ & $(13.75)^{* *}$ & $(15.73)^{* *}$ \\
\hline One or two children & -9.5 & 11.2 & 6.2 & -4.2 & 9.0 & -11.9 \\
\hline & $(1.24)$ & $(1.14)$ & $(0.69)$ & $(0.26)$ & $(0.50)$ & $(1.05)$ \\
\hline Three or more children & -29.7 & -24.1 & -19.7 & 24.4 & -4.2 & -46.1 \\
\hline & $(2.75)^{* *}$ & $(1.60)$ & $(1.47)$ & $(1.01)$ & $(0.16)$ & $(2.15)^{*}$ \\
\hline Highest Grade & 43.2 & 100.6 & 66.5 & 74.7 & 59.9 & 53.3 \\
\hline Completed & $(27.41)^{* *}$ & $(30.91)^{* *}$ & $(28.26)^{* *}$ & $(15.62)^{* *}$ & $(10.67)^{* *}$ & $(18.76)^{* *}$ \\
\hline In School & -566.5 & -533.8 & -561.9 & -477.3 & -449.8 & -492.5 \\
\hline & $(60.17)^{* *}$ & $(56.50)^{* *}$ & $(61.62)^{* *}$ & $(25.73)^{* *}$ & $(20.51)^{* *}$ & $(49.00)^{* *}$ \\
\hline Residence in Urban Area & -14.6 & 43.2 & 16.5 & 72.3 & 26.3 & -1.5 \\
\hline & $(2.04)^{*}$ & $(4.50)^{* *}$ & $(1.90)^{*}$ & $(4.02)^{* *}$ & $(1.41)$ & $(0.12)$ \\
\hline County Employment & 1.9 & 1.1 & 1.3 & -1.4 & 0.8 & 2.7 \\
\hline Growth & $(2.28)^{*}$ & $(1.42)$ & $(1.68)^{*}$ & $(0.88)$ & $(0.51)$ & $(3.13)^{* *}$ \\
\hline County Unemployment & -7.3 & -15.2 & -12.2 & -21.2 & -20.1 & -10.7 \\
\hline Rate & $(8.40)^{* *}$ & $(13.41)^{* *}$ & $(11.87)^{* *}$ & $(9.16)^{* *}$ & $(9.81)^{* *}$ & $(8.75)^{* *}$ \\
\hline Constant & 2695.2 & 2274.8 & 2743.7 & 2554.2 & 2556.6 & 3784.6 \\
\hline & $(33.93)^{* *}$ & $(25.46)^{* *}$ & $(33.23)^{* *}$ & $(16.84)^{* *}$ & $(15.90)^{* *}$ & $(20.12)^{* *}$ \\
\hline Observations & 61,234 & 61,234 & 61,234 & 17,366 & 16,241 & 34,750 \\
\hline Number of Individuals & & 2,863 & 2,863 & 816 & 769 & 2,863 \\
\hline
\end{tabular}

Notes: Absolute value of $t$-statistics in parentheses. ${ }^{*}$ significant at $5 \%$ level, and ${ }^{* *}$ significant at $1 \%$ level 
Appendix Table B-3: Determinants of Ln Hourly Wage: All Independent Variables

\begin{tabular}{|c|c|c|c|c|c|c|}
\hline & $\begin{array}{c}(1) \\
\text { OLS }\end{array}$ & $\begin{array}{c}\text { (2) } \\
\text { Fixed Effects }\end{array}$ & $\begin{array}{c}\text { (3) } \\
\text { Random Effects }\end{array}$ & $\begin{array}{c}(4) \\
\text { Black }\end{array}$ & $\begin{array}{c}\text { (5) } \\
\text { Low AFQT }\end{array}$ & $\begin{array}{c}(6) \\
\text { No Hours }\end{array}$ \\
\hline \multirow[t]{2}{*}{ Entry into first marriage } & 0.118 & 0.076 & 0.085 & 0.094 & 0.070 & 0.097 \\
\hline & $(10.77)^{* *}$ & $(7.92)^{* *}$ & $(8.89)^{* *}$ & $(4.71)^{* *}$ & $(3.55)^{* *}$ & $(10.03)^{* *}$ \\
\hline \multirow[t]{2}{*}{ Continuing marriage } & 0.175 & 0.119 & 0.129 & 0.133 & 0.109 & 0.197 \\
\hline & $(32.28)^{* *}$ & $(18.09)^{* *}$ & $(20.76)^{* *}$ & $(10.82)^{* *}$ & $(8.66)^{* *}$ & $(32.40)^{* *}$ \\
\hline \multirow[t]{2}{*}{ Entry into divorce } & 0.106 & 0.066 & 0.074 & 0.096 & 0.100 & 0.124 \\
\hline & $(7.03)^{* *}$ & $(4.86)^{* *}$ & $(5.52)^{* *}$ & $(3.75)^{* *}$ & $(4.11)^{* *}$ & $(9.09)^{* *}$ \\
\hline \multirow[t]{2}{*}{ Continuing divorce } & 0.057 & 0.029 & 0.035 & 0.061 & 0.089 & 0.073 \\
\hline & $(7.02)^{* *}$ & $(2.95)^{* *}$ & $(3.82)^{* *}$ & $(3.66)^{* *}$ & $(5.46)^{* *}$ & $(7.93)^{* *}$ \\
\hline \multirow[t]{2}{*}{ Entry into remarriage } & 0.119 & 0.071 & 0.080 & 0.123 & 0.158 & 0.137 \\
\hline & $(5.87)^{* *}$ & $(3.95)^{* *}$ & $(4.46)^{* *}$ & $(3.28)^{* *}$ & $(4.79)^{* *}$ & $(7.56)^{* *}$ \\
\hline \multirow[t]{2}{*}{ Work Experience (hours) } & 0.024 & 0.024 & 0.023 & 0.016 & 0.015 & \\
\hline & $(31.11)^{* *}$ & $(25.65)^{* *}$ & $(26.81)^{* *}$ & $(9.73)^{* *}$ & $(9.29)^{* *}$ & \\
\hline \multirow[t]{2}{*}{ Experience squared } & 0.000 & 0.000 & 0.000 & 0.000 & 0.000 & \\
\hline & $(16.37)^{* *}$ & $(13.81)^{* *}$ & $(14.09)^{* *}$ & $(3.68)^{* *}$ & $(5.03)^{* *}$ & \\
\hline \multirow[t]{2}{*}{ Age } & -0.005 & -0.006 & -0.002 & 0.007 & 0.013 & 0.032 \\
\hline & $(1.37)$ & $(1.45)$ & $(0.58)$ & $(1.06)$ & $(2.01)^{*}$ & $(11.73)^{* *}$ \\
\hline \multirow[t]{2}{*}{ Age Squared } & 0.000 & 0.000 & 0.000 & 0.000 & 0.000 & 0.000 \\
\hline & $(2.34)^{*}$ & $(2.54)^{*}$ & $(3.44)^{* *}$ & $(2.96)^{* *}$ & $(3.42)^{* *}$ & $(7.04)^{* *}$ \\
\hline \multirow{2}{*}{ Black } & -0.044 & & -0.062 & & & -0.099 \\
\hline & $(7.87)^{* *}$ & & $(4.34)^{* *}$ & & & $(6.59)^{* *}$ \\
\hline \multirow[t]{2}{*}{ Hispanic } & 0.011 & & 0.013 & & & -0.004 \\
\hline & $(1.91)$ & & $(0.85)$ & & & $(0.25)$ \\
\hline \multirow[t]{2}{*}{ AFQT } & 0.026 & & 0.013 & 0.021 & 0.130 & 0.022 \\
\hline & $(21.03)^{* *}$ & & $(4.40)^{* *}$ & $(2.96)^{* *}$ & $(3.66)^{* *}$ & $(7.06)^{* *}$ \\
\hline \multirow[t]{2}{*}{ Family Income, 1979} & 1.769 & & 1.719 & 0.674 & 1.396 & 2.163 \\
\hline & $(13.14)^{* *}$ & & $(4.80)^{* *}$ & $(0.81)$ & (1.33) & $(5.78)^{* *}$ \\
\hline \multirow[t]{2}{*}{ Missing Family Income } & 0.054 & & 0.054 & 0.039 & 0.046 & 0.068 \\
\hline & $(9.24)^{* *}$ & & $(3.49)^{* *}$ & $(1.45)$ & $(1.66)^{*}$ & $(4.19)^{* *}$ \\
\hline \multirow[t]{2}{*}{ Mother's Education } & 0.001 & & -0.002 & 0.002 & 0.005 & -0.003 \\
\hline & $(1.61)$ & & $(1.05)$ & $(0.39)$ & $(1.34)$ & $(1.35)$ \\
\hline \multirow[t]{2}{*}{ Illegal } & 0.028 & & 0.050 & 0.054 & -0.013 & 0.002 \\
\hline & $(4.81)^{* *}$ & & $(3.21)^{* *}$ & $(1.88)^{*}$ & $(0.50)$ & $(0.14)$ \\
\hline \multirow[t]{2}{*}{ Job Tenure } & 0.012 & 0.010 & 0.010 & 0.017 & 0.013 & \\
\hline & $(19.36)^{* *}$ & $(14.12)^{* *}$ & $(15.02)^{* *}$ & $(12.08)^{* *}$ & $(8.74)^{* *}$ & \\
\hline \multirow[t]{2}{*}{ Number of Jobs } & -0.005 & -0.003 & -0.003 & 0.000 & -0.001 & \\
\hline & $(10.01)^{* *}$ & $(3.21)^{* *}$ & $(4.54)^{* *}$ & $(0.26)$ & $(0.54)$ & \\
\hline \multirow[t]{2}{*}{ Highest Grade Completed } & 0.057 & 0.097 & 0.081 & 0.083 & 0.025 & 0.072 \\
\hline & $(51.32)^{* *}$ & $(45.44)^{* *}$ & $(45.94)^{* *}$ & $(22.49)^{* *}$ & $(5.61)^{* *}$ & $(40.25)^{* *}$ \\
\hline In School & -0.207 & -0.181 & -0.196 & -0.146 & -0.051 & -0.204 \\
\hline & $(31.40)^{* *}$ & $(29.58)^{* *}$ & $(32.94)^{* *}$ & $(12.64)^{* *}$ & $(3.80)^{* *}$ & $(33.87)^{* *}$ \\
\hline GED Level & -0.05 & -0.172 & -0.119 & -0.109 & 0.000 & -0.174 \\
\hline & $(6.96)^{* *}$ & $(12.70)^{* *}$ & $(10.53)^{* *}$ & $(6.14)^{* *}$ & $(0.01)$ & $(15.11)^{* *}$ \\
\hline Residence in Urban Area & 0.018 & -0.001 & 0.003 & -0.003 & 0.005 & -0.002 \\
\hline & $(3.40)^{* *}$ & $(0.18)$ & $(0.50)$ & $(0.28)$ & $(0.43)$ & $(0.40)$ \\
\hline County Average Earnings & 0.029 & 0.019 & 0.022 & 0.010 & 0.014 & 0.022 \\
\hline & $(46.06)^{* *}$ & $(22.33)^{* *}$ & $(27.40)^{* *}$ & $(6.92)^{* *}$ & $(8.74)^{* *}$ & $(27.68)^{* *}$ \\
\hline County Employment & 0.003 & 0.000 & 0.001 & 0.002 & 0.001 & 0.001 \\
\hline Growth & $(5.53)^{* *}$ & $(0.75)$ & $(1.21)$ & $(1.78)^{*}$ & $(0.75)$ & $(1.63)$ \\
\hline Constant & 0.54 & 0.345 & 0.402 & 0.303 & 0.726 & -0.083 \\
\hline & $(10.25)^{* *}$ & $(6.56)^{* *}$ & $(7.32)^{* *}$ & $(3.00)^{* *}$ & $(7.18)^{* *}$ & $(1.83)^{*}$ \\
\hline Observations & 61,234 & 61,234 & 61,234 & 17,366 & 16,241 & 61,234 \\
\hline Number of Individuals & & 2,863 & 2,863 & 816 & 769 & 2,863 \\
\hline
\end{tabular}

Notes: Absolute value of $t$-statistics in parentheses. ${ }^{*}$ significant at $5 \%$ level, and $* *$ significant at $1 \%$ level 